\title{
Effect of Myofascial Therapy on Pain and Functionality of the Upper Extremities in Breast Cancer Survivors: A Systematic Review and Meta-Analysis
}

\author{
Inmaculada Carmen Lara-Palomo ${ }^{1, * \mathbb{D}}$, Adelaida María Castro-Sánchez ${ }^{1} \mathbb{D}$, Marta María Córdoba-Peláez ${ }^{1}$, \\ Manuel Albornoz-Cabello ${ }^{2}$ (D) and Lucía Ortiz-Comino ${ }^{3}$ (D) \\ 1 Department of Nursing, Physical Therapy and Medicine, University of Almeria, Road Sacramento s/n, \\ 04120 Almeria, Spain; adelaid@ual.es (A.M.C.-S.); martamcordoba@gmail.com (M.M.C.-P.) \\ 2 Department of Physiotherapy, University of Sevilla, Avicena Street s/n, 41009 Sevilla, Spain; malbornoz@us.es \\ 3 Department of Physical Therapy, University of Granada, Technological Park of Health Sciences, \\ Avenue of Illustration 60, 18071 Granada, Spain; luciaoc@ugr.es \\ * Correspondence: inma.lara.palomo@gmail.com; Tel.: +34-655-388-324
}

Citation: Lara-Palomo, I.C.;

Castro-Sánchez, A.M.;

Córdoba-Peláez, M.M.;

Albornoz-Cabello, M.; Ortiz-Comino, L. Effect of Myofascial Therapy on

Pain and Functionality of the Upper

Extremities in Breast Cancer

Survivors: A Systematic Review and

Meta-Analysis. Int. J. Environ. Res.

Public Health 2021, 18, 4420 .

https://doi.org/10.3390/

ijerph18094420

Academic Editor:

María M. Morales Suárez-Varela

Received: 9 March 2021

Accepted: 19 April 2021

Published: 21 April 2021

Publisher's Note: MDPI stays neutral with regard to jurisdictional claims in published maps and institutional affiliations.

Copyright: (c) 2021 by the authors. Licensee MDPI, Basel, Switzerland. This article is an open access article distributed under the terms and conditions of the Creative Commons Attribution (CC BY) license (https:/ / creativecommons.org/licenses/by/ $4.0 /)$.
Abstract: (1) Objective: The purpose was to analyze the effectiveness of myofascial therapy on musculoskeletal pain and functionality of the upper extremities in female breast cancer survivors, and to evaluate the changes in range of motion, quality of life, and mood state of these patients. (2) Methods: Systematic searches were performed on the MEDLINE/PubMed, Web of Science, Scopus, and Physiotherapy Evidence Databases for articles published until October 2020, in order to identify randomized controlled trials which analyzed the effectiveness of myofascial therapy as compared to a control group, passive treatment, placebo, or another intervention, and allowed co-interventions on female breast cancer survivors. Two reviewers examined the sources individually, calculated the risk of bias and extracted the data (PROSPERO number CRD42020215823). (3) Results: A total of eight RCTs were included. The results suggested that myofascial therapy does not have a greater statistically significant immediate effect on pain intensity (SMD: -0.15 ; 95\% CI $-0.48,0.19$ ), functionality (SMD: -0.17 ; $95 \% \mathrm{CI}-0.43,0.09$ ) and range of motion in flexion (SMD: $0.30 ; 95 \% \mathrm{CI}-0.13,0.74)$ than an inactive, passive treatment or another intervention. However, a statistically significant result was observed for the abduction shoulder in favor of the experimental group (SMD: 0.46 ; 95\% CI 0.05, 0.87; $p=0.03$ ). (4) Conclusion: In general, although we found greater overall effects in support of the intervention with myofascial therapy than other control groups/types of interventions, the subgroup analysis revealed inconsistent results supporting myofascial therapy applied to breast cancer survivors.

Keywords: breast cancer; myofascial release; functionality; pain; quality of life; range of motion

\section{Introduction}

Of the 18.1 million cases of cancer globally diagnosed [1], breast cancer accounts for $11.6 \%$, being the most common cancer among women $[2,3]$. In Spain, this incidence increases to $28.7 \%$, and one in eight women is at risk of developing breast cancer [4]. The rising incidence of breast cancer in developed countries is mainly due to demographic factors, lifestyle, and reproduction rates [5]. Despite this high incidence, thanks to developments in early detection techniques, as well as rapid implementation of treatment protocols [6], its survival rate is over 90\% [7].

Treatment of breast cancer generally involves a combination of different methods, and may produce toxicities, which can be cumulative and difficult to separate clinically, including surgery, radiation, chemotherapy, hormonal therapy, and/or targeted therapy $[8,9]$. Surgical treatment for breast cancer includes breast-conserving surgery, combined with radiation, or mastectomy with or without radiation and with or without immediate/deferred reconstruction [9]. Breast-conserving therapy, consisting of breast-conserving surgery 
(lumpectomy) plus radiation, is the standard treatment for most women with stage I and II breast carcinomas [10]. However, all survivors are at risk of suffering from side effects of treatment in the short- or long-term, such as hemorrhage, infection at the surgical site, weakness in the arm or shoulder, restricted movement, swelling, numbness, pain, and lymphedema [11-15].

Radiation therapy is an adjuvant therapy that is used in $50 \%$ of patients, which may lead to fibrosis in the adjacent tissue [8]. Radiation-induced fibrosis is a form of damage to normal tissues after radiation therapy. It can affect the underlying fascia, muscles, organs, and bones on both the affected and unaffected sides, cause persistent symptoms and aesthetic disfigurement, thereby affecting quality of life [16-19].

Furthermore, the dissection of the axillary lymph nodes, the radiation on the regional lymph nodes and the patient's preoperative body mass index, among others, are considered to be factors that contribute to the development of one of the most frequent side effects of breast cancer: lymphedema [20]. The risk of getting lymphedema after overcoming cancer is between $6 \%$ and $45 \%$ [21-24] and, of these cases, $90 \%$ arise between 18 and 24 months after treatment [20,25]. Additionally, lymphedema is associated with other symptoms, such as pain, bloating, pressure, fatigue, limited joint movement, mainly in the abduction of the shoulder and elbow bending, and the subsequent reduction in use of the affected limb $[22,26]$. Conversely, postoperative pain is another side effect which occurs in at least half of women who have undergone surgery between 6-15 months after the operation [27,28]. The prevalence of neuropathic pain is $24 \%$ nine months after surgery [28].

While improvement in diagnostic processes and in the choices available for medical treatment to reduce possible long-term effects have led to a higher survival rate after breast cancer diagnosis, new challenges have arisen in addressing these effects in healthcare systems [29]. There are several studies which suggest the use of physical therapy to treat side effects of breast cancer following medical treatment. Among the most highlyrecommended therapies are mobilization, active exercises or active-assisted exercises, and manual therapy [30-32]. Myofascial release is found under the scope of manual therapy, and is a low-impact, long-term treatment with the aim of restoring the length of the fascia, eliminating functional limitations and reducing the perception of pain to improve the function of the locomotor system [33]. Numerous clinical trials have demonstrated the benefits of myofascial therapy on different populations, showing an improvement in range of motion and a decrease in perceived pain [34-37]. However, to date, no systematic reviews nor meta-analyses have been carried out about the effects of myofascial therapy on the treatment of the side effects derived from the medical treatment of breast cancer, whereas because of its characteristics as a manual therapy specialty as well as the absence of secondary side-effects after its use [33], it seems an adequate technique to manage with breast cancer survivors' impairments.

Thus, the objective of this study is to perform a systematic review, together with a meta-analysis, to check the effects of myofascial therapy on female breast cancer survivors pain, functionality, joint range of motion, and mood state. We hypothesize that myofascial release is an adequate approach to improve these factors.

\section{Materials and Methods}

\subsection{Protocol and Registry}

A systematic review and meta-analysis was carried out, taking into account the items on the recent declaration of 'preferred reporting items for systematic reviews and metaanalyses' (PRISMA) [38]. Systematic review registration: http://www.crd.york.ac.uk/ PROSPERO (accessed on 21 April 2021). PROSPERO registration number: CRD42020215823 (23 November 2020).

\subsection{Search and Information Sources}

The bibliographic search was performed during the months of March through October 2020 on the Medline (through the platform PubMed), Scopus, Web of Science, and PEDro 
databases. The search strategy was based on terms registered on the MeSH list ("breast", "cancer", and "myofascial") combined with the Boolean operator (AND), adapted to the characteristics of each database. Any duplicates that were identified in the multiple database searches were removed. Additionally, the reference lists for the included studies were also examined and experts in the field were contacted (for example, authors of the included studies) to obtain additional information or information which was not implicit in the published trials.

\subsection{Inclusion and Exclusion Criteria}

The inclusion and exclusion criteria were defined using the PICO process [39] (Patient, Problem or Population, Intervention, Comparison, Control or Comparator, Outcome(s)).

\subsubsection{Types of Studies}

Randomized controlled clinical trials (RCTs) were included. Quasi-experimental controlled trials were excluded. In addition, the following inclusion criteria were taken into account: RCTs published in the last 20 years (from 2000 onwards), written in English, available in full-text version, focused on the ongoing effects of breast cancer intervention with myofascial techniques. All studies that did not meet these characteristics were excluded.

\subsubsection{Types of Participants}

Studies with female subjects who had completed breast cancer treatment at least two months prior and had upper limb or neck pain. An exception was made with one of the studies, which was related to palliative care, but was included, as the same aspects were assessed as in the other studies. The age of participants and tumor location were not considered as criteria.

\subsubsection{Types of Interventions}

Studies were included in which side effects derived from breast cancer treatment were treated with myofascial therapy. Studies that treated these effects with myofascial therapy accompanied by other manual or physical therapies were not excluded, nor were studies restricted by the duration of treatment, frequency or type of techniques applied in the treatment. Studies comparing myofascial therapy with any other intervention or no intervention were included. We also included any study which compared myofascial therapy accompanied by other therapies, with only the application of those other therapies. All habitual medication was allowed to be taken during the studies.

\subsubsection{Types of Outcome Measures}

Studies that evaluated one or both of the following aspects as primary measures were chosen: pain and functionality of the shoulder affected. For pain, the studies should have used the Visual Analogue Scale (VAS), or a comparable numerical scale, and in the evaluation of functionality, the Disabilities of the Arm, Shoulder and Hand (DASH), or scale should have been used. As a secondary outcome measure, the following were also taken into consideration: the evaluation of shoulder mobility using goniometry; the mood state of the participants evaluated, for example, with the Profile of Mood States (POMS) scale; and quality of life measured using the Health Questionnaire SF-36. The results were collected in three specific time periods: immediately following treatment, short-term ( $\leq 3$ months), medium-term (between six and nine months), and long-term ( $\geq 12$ months).

\subsection{Study Selection}

Two reviewers (I.C.L.-P., M.M.C.-P.) used the pre-specified criteria to select relevant titles, abstracts and full articles. An article was deleted if it was determined that it did not meet the inclusion criteria. If there were any hesitations about the selection decisions, a third reviewer (A.M.C.-S.) was consulted. Once the review was completed, the search strategy was repeated, in case any new studies had been published, and they were analyzed to assess their inclusion. The last search was carried out in November 2020. 


\subsection{Data Extraction and Management}

Firstly, the titles and abstracts of the references retrieved from the searches were selected. The full text was obtained for references which the authors considered potentially relevant. Full-text references were then independently evaluated for inclusion according to the inclusion criteria for considering studies for this review.

To manage the data, a data summary sheet was created, based on the Cochrane recommendations. The data extracted were: author and year, type of study, number and type of patients, type of intervention, number and duration of treatment sessions, outcome measures, and primary outcomes found among groups. If key information was missing from the study report, the authors of the report were contacted to obtain this information.

\subsection{Risk of Bias Assessment}

We used the recommendations from the Cochrane Collaboration to evaluate the risk of bias for all of the articles. Each item was evaluated with the objective of discerning whether the trials eligible for inclusion in this review were valid enough for their results to be interpreted. The items evaluated were: specification of selection criteria, random sequence generation, homogeneity among groups, allocation concealment, blinding of participants and personnel, blinding of the outcome assessors, incomplete outcome data, selective reports, and other biases.

Two reviewers (I.C.L.-P., L.O.-C.) independently assessed the risk of bias for each of the articles selected for the current study. An arbitrator (A.M.C.-S.) was consulted to settle any disagreements.

Each item was classified as "high risk", "low risk", or "unclear risk" of bias. A sensitivity analysis was performed on the primary results to explore the effects of including and excluding trials with a high risk of bias (sensitivity analysis).

\subsection{Statistical Analysis}

A heterogeneity analysis of the selected studies was performed. In terms of continuous data and dichotomous data, effect sizes were measured using standardized mean difference (SMD) and 95\% confidence interval (CI), or risk ratio (RR) with $95 \% \mathrm{CI}$, respectively. Heterogeneity within RCTs was examined using the $\mathrm{I}^{2}$ test, considering $\mathrm{I}^{2} \geq 50 \%$ as a sign of substantial heterogeneity. Once there were $>2$ homogeneous studies, RevMan 5.4 (Cochran Collaboration, London, UK) software was used to perform meta-analyses. Sensitivity analyses were conducted for the robustness of the result of meta-analyses.

\section{Results}

\subsection{Selection of Studies}

The initial search retrieved 181 potential articles, of which 112 were excluded after reviewing their titles and abstracts, and 27 were duplicates, leaving 42 full-text articles to be reviewed. After the application of the inclusion and exclusion criteria, 34 of these articles were eliminated, leaving eight studies for this systematic review and meta-analysis. Figure 1 illustrates the different phases of the review, using the eligibility and data-synthesis PRISMA flow diagram.

\subsection{Characteristics of Studies Included}

Eight RCTs were included, with a total of 333 participants [40-47]. The study developed by Fernández-Lao et al., divided into two publications [40,41] contained the smallest sample-size, with 20 participants; whereas the one with the largest sample size was the study by Groef et al. [42] with 147 participants. 


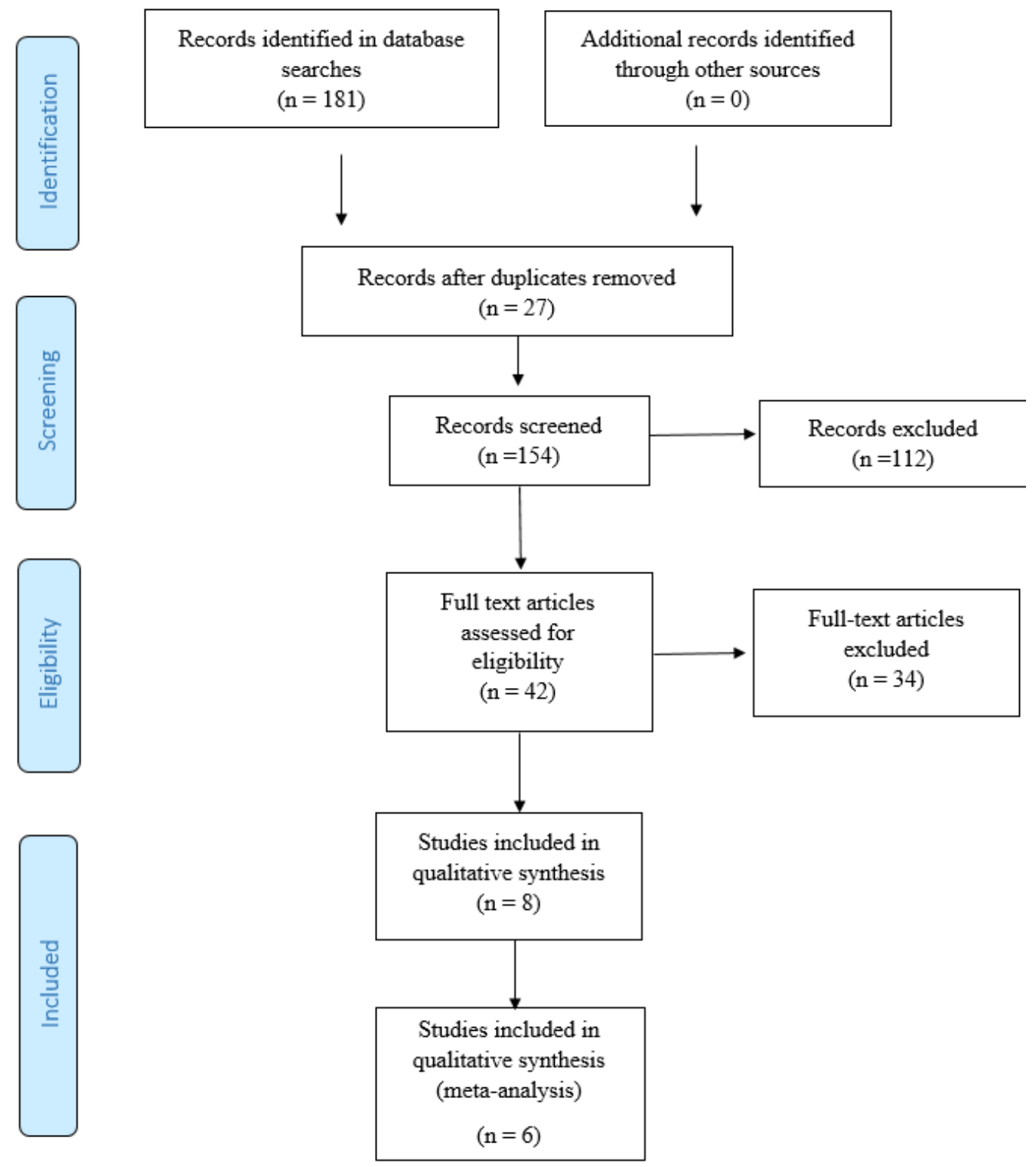

Figure 1. Eligibility and data synthesis: PRISMA flow diagram.

Regarding the location where the studies took place, three were performed in Spain [40,41,43,44], three in Belgium [42,45,46] and another in the Midwestern United States [46]. All of the studies reported the place of recruitment and methods used. The study developed by Fernández-Lao et al. were was performed on patients from the Oncological Unit at the Virgen de las Nieves Hospital in Granada, Spain [40,41]; one at the University of Granada [43]; one in Valencia, Spain, at the Spanish Association Against Cancer (AECC) [44]; three at the University Hospital in Leuven, Belgium [42,45,46]; and in the study carried out in the United States, the women interested in taking part in the study contacted the coordinator to participate [47]. Table 1 shows the main characteristics of each of the studies. 
Table 1. Characteristics of the RCTs included in this review.

\begin{tabular}{|c|c|c|c|c|c|c|c|c|}
\hline $\begin{array}{l}\text { Author and } \\
\text { Year }\end{array}$ & $\begin{array}{c}\text { Sample } \\
\text { and } \\
\text { Average Age }\end{array}$ & Diagnosis & $\begin{array}{l}\text { Type of Surgical } \\
\text { Intervention }\end{array}$ & Type of Intervention & $\begin{array}{c}\text { Sessions } \\
\text { and } \\
\text { Length of Time }\end{array}$ & $\begin{array}{l}\text { Outcome } \\
\text { Measures }\end{array}$ & Follow-Up & Results \\
\hline $\begin{array}{l}\text { Fernández- } \\
\text { Lao et al. } \\
(2012)[40]^{*}\end{array}$ & $\begin{array}{c}N=20 \\
E G=10 \\
C G=10 \\
49 \pm 8\end{array}$ & $\begin{array}{c}\text { Breast cancer } \\
\text { (I-IIIA), with } \\
\text { moderate/high } \\
\text { fatigue } \\
\text { (>6 points). }\end{array}$ & $\begin{array}{l}70 \% \text { of the women } \\
\text { had received a } \\
\text { lumpectomy and } 30 \% \\
\text { a mastectomy. } \\
\text { Adjuvant radiation } \\
\text { therapy or } \\
\text { chemotherapy. }\end{array}$ & $\begin{array}{l}\text { EG: A protocol of } \\
\text { myofascial induction } \\
\text { focused on the } \\
\text { neck-shoulder area } \\
\text { using the Barnes } \\
\text { approach. } \\
\text { CG: Educational } \\
\text { session on healthy } \\
\text { lifestyles. }\end{array}$ & $\begin{array}{c}2 \text { sessions } \\
40^{\prime} \text { / session } \\
3 \text { weeks }\end{array}$ & $\begin{array}{l}\text { PPT: algometer } \\
\left(\mathrm{kg} / \mathrm{cm}^{2}\right) \\
\text { ATOM }(0-45) \\
\text { Function of the } \\
\text { sympathetic and } \\
\text { immune system: } \\
\text { saliva samples }\end{array}$ & 3 weeks & $\begin{array}{l}\text { Increased salivary } \\
\text { flow }(p=0.010) \text { after } \\
\text { intervention with } \\
\text { myofascial therapy. In } \\
\text { addition, positive } \\
\text { attitude had a } \\
\text { significant increase in } \\
\text { IgA }(p<0.05) \text { in the } \\
\text { experimental group. } \\
\text { There were no effects } \\
\text { for PPT on the cervical } \\
\text { spine or temporalis } \\
\text { muscle. }\end{array}$ \\
\hline $\begin{array}{l}\text { Fernández- } \\
\text { Lao et al. } \\
(2011)[41]^{*}\end{array}$ & $\begin{array}{c}\mathrm{N}=20 \\
\mathrm{EG}=10 \\
\mathrm{CG}=10 \\
49 \pm 8\end{array}$ & $\begin{array}{c}\text { Breast cancer } \\
\text { (stage I-IIIA) } \\
\text { and with } \\
\text { moderate/high } \\
\text { fatigue } \\
\text { (>6 points). }\end{array}$ & $\begin{array}{l}70 \% \text { of the women } \\
\text { had received a } \\
\text { lumpectomy and } 30 \% \\
\text { a mastectomy. } \\
\text { Adjuvant radiation } \\
\text { therapy or } \\
\text { chemotherapy. }\end{array}$ & $\begin{array}{l}\text { EG: A protocol of } \\
\text { myofascial induction } \\
\text { focused on the } \\
\text { neck-shoulder area } \\
\text { using the Barnes } \\
\text { approach. } \\
\text { CG: Advice for } \\
\text { improving quality of } \\
\text { life after breast cancer. }\end{array}$ & $\begin{array}{l}2 \text { sessions } \\
40^{\prime} / \text { session } \\
2 \text { weeks }\end{array}$ & $\begin{array}{c}\text { HR variability: Holter } \\
\text { ATOM (0-45) } \\
\text { POMS }\end{array}$ & 2 weeks & $\begin{array}{l}\text { Increased HR after } \\
\text { myofascial induction } \\
\qquad(p<0.05) \\
\text { Improvement in } \\
\text { perceived fatigue and } \\
\text { general mood by } \\
\text { POMS after } \\
\text { myofascial induction } \\
(p<0.05 \text {. Improved } \\
\text { anxiety, depression } \\
\text { and anger in patients } \\
\text { with a better attitude } \\
\text { towards massage after } \\
\text { myofascial therapy } \\
(p<0.05) .\end{array}$ \\
\hline
\end{tabular}


Table 1. Cont.

\begin{tabular}{|c|c|c|c|c|c|c|c|c|}
\hline $\begin{array}{l}\text { Author and } \\
\text { Year }\end{array}$ & $\begin{array}{c}\text { Sample } \\
\text { and } \\
\text { Average Age }\end{array}$ & Diagnosis & $\begin{array}{l}\text { Type of Surgical } \\
\text { Intervention }\end{array}$ & Type of Intervention & $\begin{array}{c}\text { Sessions } \\
\text { and } \\
\text { Length of Time }\end{array}$ & $\begin{array}{l}\text { Outcome } \\
\text { Measures }\end{array}$ & Follow-Up & Results \\
\hline $\begin{array}{l}\text { Groef et al. } \\
\text { (2017) [42] }\end{array}$ & $\begin{array}{c}\mathrm{N}=147 \\
\mathrm{EG}=72 \\
\mathrm{CG}=75 \\
\mathrm{EG}: 53.9 \pm 11.5 \\
\mathrm{CG}: \\
54.7 \pm 11.9\end{array}$ & $\begin{array}{l}\text { Patients with } \\
\text { unilateral } \\
\text { axillary } \\
\text { clearance for } \\
\text { primary breast } \\
\text { cancer after } \\
\text { surgery. }\end{array}$ & $\begin{array}{c}\text { Between } 60-70 \% \\
\text { received a } \\
\text { mastectomy and } \\
\text { between } 30-40 \% \\
\text { breast conservation. } \\
\text { Adjuvant radiation } \\
\text { therapy or } \\
\text { chemotherapy. }\end{array}$ & $\begin{array}{l}\text { EG: Standard physical } \\
\text { therapy program and } \\
\text { myofascial induction } \\
\text { (in active trigger } \\
\text { points of the affected } \\
\text { limb and in adhesions } \\
\text { of the pectoral, } \\
\text { axillary and cervical } \\
\text { region, diaphragm } \\
\text { and scar). } \\
\text { CG: Standard physical } \\
\text { therapy intervention } \\
\text { and placebo } \\
\text { intervention (static } \\
\text { hand placement on } \\
\text { the upper body } \\
\text { and arm). }\end{array}$ & $\begin{array}{c}8 \text { sessions } \\
30^{\prime} / \text { session } \\
8 \text { weeks }\end{array}$ & $\begin{array}{c}\text { VAS }(0-100) \\
\text { DASH }(0-100) \\
\text { SF-36 }(0-100) \\
\text { PPT: algometer } \\
\text { (kg/cm²) } \\
\text { McGill Pain } \\
\text { Questionnaire }\end{array}$ & $\begin{array}{c}8 \text { weeks } \\
9 \text { and } \\
12 \text { months }\end{array}$ & $\begin{array}{l}\text { The PPT in the upper } \\
\text { trapezius ( } p=0.012) \\
\text { was significantly } \\
\text { higher at } 4 \text { months in } \\
\text { the intervention } \\
\text { group, and at } 4 \text { and } \\
9 \text { months in } \\
\text { supraspinatus } \\
(p=0.021) \text { and } \\
(p=0.040), \\
\text { respectively. }\end{array}$ \\
\hline
\end{tabular}


Table 1. Cont.

\begin{tabular}{|c|c|c|c|c|c|c|c|c|}
\hline $\begin{array}{c}\text { Author and } \\
\text { Year }\end{array}$ & $\begin{array}{c}\text { Sample } \\
\text { and } \\
\text { Average Age }\end{array}$ & Diagnosis & $\begin{array}{l}\text { Type of Surgical } \\
\text { Intervention }\end{array}$ & Type of Intervention & $\begin{array}{c}\text { Sessions } \\
\text { and } \\
\text { Length of Time }\end{array}$ & $\begin{array}{l}\text { Outcome } \\
\text { Measures }\end{array}$ & Follow-Up & Results \\
\hline $\begin{array}{c}\text { Castro- } \\
\text { Martín et al. } \\
(2016)[43]\end{array}$ & $\begin{array}{c}N=21 \\
E G=11 \\
C G=10 \\
25-65\end{array}$ & $\begin{array}{l}\text { Breast cancer in } \\
\text { stage I-IIIA. }\end{array}$ & $\begin{array}{l}\text { The types of surgery } \\
\text { were: lumpectomy, } \\
\text { quadrantectomy, } \\
\text { unilateral mastectomy, } \\
\text { mastectomy and } \\
\text { lymphadenectomy. } \\
\text { All patients had } \\
\text { received radiotherapy } \\
\text { and chemotherapy. }\end{array}$ & $\begin{array}{c}\text { EG: Myofascial } \\
\text { induction in the upper } \\
\text { limb area, following } \\
\text { the Pilat approach. } \\
\text { CG: Simulated pulsed } \\
\text { short wave } \\
\text { (disconnected) }\end{array}$ & $\begin{array}{c}2 \text { sessions } \\
30^{\prime} \text { / session } \\
4 \text { weeks }\end{array}$ & $\begin{array}{c}\text { VAS }(0-100) \\
\text { Shoulder mobility: } \\
\text { Goniometer } \\
\text { POMS } \\
\text { ATOM Scale }(0-45)\end{array}$ & 4 weeks & $\begin{array}{l}\text { The VAS improved } \\
\text { after myofascial } \\
\text { induction in the } \\
\text { affected arm } \\
(p=0.031) \text {, as well as } \\
\text { flexion, abduction and } \\
\text { external and internal } \\
\text { rotations of the } \\
\text { affected arm ( } p<0.05) \text {, } \\
\text { and cervical rotation } \\
\text { and inclination } \\
\text { towards the affected } \\
\text { side ( } p<0.05) \text {. } \\
\text { After myofascial } \\
\text { induction there were } \\
\text { also improvements in } \\
\text { mood, anxiety, } \\
\text { depression, anger, } \\
\text { vigor, fatigue and } \\
\text { confusion }(p<0.05) \text {. } \\
\text { There were no } \\
\text { significant changes on } \\
\text { the ATOMS scale. }\end{array}$ \\
\hline
\end{tabular}


Table 1. Cont.

\begin{tabular}{|c|c|c|c|c|c|c|c|c|}
\hline $\begin{array}{c}\text { Author and } \\
\text { Year }\end{array}$ & $\begin{array}{c}\text { Sample } \\
\text { and } \\
\text { Average Age }\end{array}$ & Diagnosis & $\begin{array}{l}\text { Type of Surgical } \\
\text { Intervention }\end{array}$ & Type of Intervention & $\begin{array}{c}\text { Sessions } \\
\text { and } \\
\text { Length of Time }\end{array}$ & $\begin{array}{l}\text { Outcome } \\
\text { Measures }\end{array}$ & Follow-Up & Results \\
\hline $\begin{array}{l}\text { Serra-añó et al. } \\
\text { (2018) [44] }\end{array}$ & $\begin{array}{c}\mathrm{N}=24 \\
\mathrm{EG}=13 \\
\mathrm{CG}=11 \\
\mathrm{EG}: \\
53.15 \pm 10.91 \\
\mathrm{CG}: 54.36 \pm 6.86\end{array}$ & $\begin{array}{l}\text { Breast cancer } \\
\text { with } \\
\text { conservative } \\
\text { treat- } \\
\text { ment/surgery at } \\
\text { least } 4 \text { months } \\
\text { before, without } \\
\text { lymphedema or } \\
\text { in stage I. }\end{array}$ & $\begin{array}{l}\text { Conservative/partial } \\
\text { surgery with or } \\
\text { without stage I } \\
\text { lymphedema. }\end{array}$ & $\begin{array}{l}\text { EG: Myofascial } \\
\text { induction through } \\
\text { four maneuvers. } \\
\text { CG: Placebo manual } \\
\text { lymphatic drainage }\end{array}$ & $\begin{array}{l}4 \text { sessions } \\
50^{\prime} / \text { session } \\
4 \text { weeks }\end{array}$ & $\begin{array}{c}\text { VAS }(0-100) \\
\text { Shoulder mobility } \\
\text { range. } \\
\text { DASH }(0-100) \\
\text { PHQ-9 }(0-100) \\
\text { FACT-B + } 4\end{array}$ & $\begin{array}{l}4 \text { weeks } \\
1 \text { month }\end{array}$ & $\begin{array}{l}\text { Only the participants } \\
\text { who received } \\
\text { myofascial induction } \\
\text { had improved pain } \\
\text { intensity, range of } \\
\text { motion in flexion, } \\
\text { extension, abduction } \\
\text { and external rotation } \\
\text { of the shoulder } \\
\text { ( } p<0.05) \text {, and } \\
\text { physical well-being } \\
\text { and the general scale } \\
\text { of quality of life } \\
(p<0.05) .\end{array}$ \\
\hline $\begin{array}{l}\text { Groef et al. } \\
\text { (2017) [45] }\end{array}$ & $\begin{array}{c}\mathrm{N}=50 \\
\mathrm{EG}=23 \\
\mathrm{CG}=25 \\
\mathrm{EG}: 55.3 \pm 7.5 \\
\mathrm{CG}: 53.1 \pm 7.5\end{array}$ & $\begin{array}{c}\text { Unilateral breast } \\
\text { cancer with pain } \\
\text { (VAS > } 4 \text { points) } \\
\text { and myofascial } \\
\text { dysfunctions in } \\
\text { the upper limb } \\
\text { area. }\end{array}$ & $\begin{array}{c}\text { Between } 60-70 \% \\
\text { received a } \\
\text { mastectomy and } \\
\text { between } 30-40 \% \\
\text { breast conservation. }\end{array}$ & $\begin{array}{l}\text { EG: Standard physical } \\
\text { therapy program and } \\
\text { myofascial induction } \\
\text { CG: Standard physical } \\
\text { therapy intervention } \\
\text { and placebo } \\
\text { intervention }\end{array}$ & $\begin{array}{l}20 \text { sessions } \\
60^{\prime} / \text { session } \\
12 \text { weeks }\end{array}$ & $\begin{array}{l}\text { Shoulder mobility } \\
\text { range. } \\
\text { Presence of } \\
\text { lymphedema } \\
\text { Force Dynamics and } \\
\text { scapular position: } \\
\text { dynamometry. } \\
\text { Acromion-table index. } \\
\text { Inclinometer. } \\
\text { DASH }(0-100) \\
\text { SF-36 }\end{array}$ & $\begin{array}{l}3 \text { months } \\
12 \text { months }\end{array}$ & $\begin{array}{l}\text { After the intervention, } \\
\text { the pain intensity } \\
\text { significantly } \\
\text { decreased for } \\
\text { participants in the } \\
\text { experimental group } \\
(p<0.046) \text {. In the } \\
\text { SF-36, mental function } \\
\text { improved after } \\
\text { myofascial induction } \\
(p<0.05) .\end{array}$ \\
\hline
\end{tabular}


Table 1. Cont

\begin{tabular}{|c|c|c|c|c|c|c|c|c|}
\hline $\begin{array}{l}\text { Author and } \\
\text { Year }\end{array}$ & $\begin{array}{c}\text { Sample } \\
\text { and } \\
\text { Average Age }\end{array}$ & Diagnosis & $\begin{array}{l}\text { Type of Surgical } \\
\text { Intervention }\end{array}$ & Type of Intervention & $\begin{array}{c}\text { Sessions } \\
\text { and } \\
\text { Length of Time }\end{array}$ & $\begin{array}{l}\text { Outcome } \\
\text { Measures }\end{array}$ & Follow-Up & Results \\
\hline $\begin{array}{l}\text { Groef et al. } \\
\text { (2017) [46] }\end{array}$ & $\begin{array}{c}\quad N=50 \\
E G=23 \\
C G=25 \\
\text { EG: } 55.36 \pm 7.5 \\
\text { CG: } 53.1 \pm 7.5\end{array}$ & $\begin{array}{c}\text { Unilateral breast } \\
\text { cancer with pain } \\
\text { (VAS > } 4 \text { points) } \\
\text { and myofascial } \\
\text { dysfunctions in } \\
\text { the upper limb } \\
\text { area. }\end{array}$ & $\begin{array}{l}\text { Between } 60-70 \% \\
\text { received a } \\
\text { mastectomy and } \\
\text { between } 30-40 \% \\
\text { breast conservation. }\end{array}$ & $\begin{array}{l}\text { EG: Standard physical } \\
\text { therapy program and } \\
\text { myofascial induction } \\
\text { CG: Standard physical } \\
\text { therapy intervention } \\
\text { and placebo } \\
\text { intervention }\end{array}$ & $\begin{array}{l}20 \text { sessions } \\
60^{\prime} / \text { session } \\
12 \text { weeks }\end{array}$ & $\begin{array}{c}\text { VAS }(0-100) \\
\text { McGill } \\
\text { PPT: algometer } \\
\left(\mathrm{kg} / \mathrm{cm}^{2}\right) \\
\text { Shoulder } \\
\text { functionality: DASH } \\
(0-100) \\
\text { SF-36 }(0-100)\end{array}$ & $\begin{array}{l}3 \text { months } \\
6 \text { and } 12 \\
\text { months }\end{array}$ & $\begin{array}{l}\text { Increase in the } \\
\text { external scale of the } \\
\text { scapula in } \\
\text { the experimental } \\
\text { group }(p<0.05) \text { and } \\
\text { improvement in } \\
\text { physical function } \\
\text { related to quality of } \\
\text { life }(p=0.018) \text {. }\end{array}$ \\
\hline $\begin{array}{l}\text { Massingill et al. } \\
\text { (2018) [47] }\end{array}$ & $\begin{array}{c}\mathrm{N}=21 \\
\mathrm{EG}=11 \\
\mathrm{CG}=10 \\
\mathrm{EG} / \mathrm{CG}: \\
21-55+\end{array}$ & $\begin{array}{l}\text { Breast cancer } \\
\text { patients who } \\
\text { have persistent } \\
\text { pain and } \\
\text { mobility } \\
\text { limitations after } \\
\text { breast cancer } \\
\text { surgery. }\end{array}$ & $\begin{array}{l}\text { The types of breast } \\
\text { cancer surgery } \\
\text { included biopsy, } \\
\text { lumpectomy, } \\
\text { mastectomy or certain } \\
\text { types of } \\
\text { reconstruction. }\end{array}$ & $\begin{array}{c}\text { EG: Myofascial } \\
\text { massage } \\
\text { CG: Relaxing massage }\end{array}$ & $\begin{array}{l}\text { Two } 30-\text { min } \\
\text { sessions a week } \\
\text { for } 8 \text { weeks }\end{array}$ & $\begin{array}{c}\text { Pain }(0-30 \text {, with } 0 \\
\text { being nothing and } \\
30 \text { being the } \\
\text { maximum }) \\
\text { Mobility }(0-40) \\
\text { Quality of life }(0-100)\end{array}$ & 8 weeks. & $\begin{array}{c}\text { The EG experienced } \\
\text { more favorable } \\
\text { changes in pain than } \\
\text { the CG }(-10.7 \mathrm{vs} . \\
+0.4, p<0.001) \\
\text { mobility } \\
(-14.5 \mathrm{vs} .-0.8, \\
p<0.001) \text { and overall } \\
\text { health }(+29.5 \text { vs. }-2.5, \\
p=0.002) \text { after } \\
8 \text { weeks }\end{array}$ \\
\hline
\end{tabular}

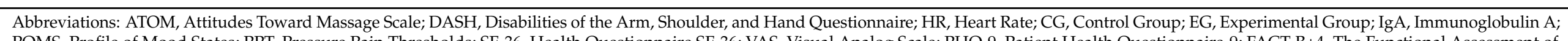

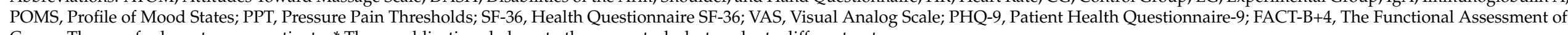
Cancer Therapy for breast cancer patients. ${ }^{*}$ These publications belong to the same study, but evaluate different outcomes. 


\subsection{Characteristics of the Participants}

All of the studies contained participants diagnosed with breast cancer. No distinction or mention of race is made in any study. The age of the patients was detailed in all of the studies, ranging from 21-65 years old [40-47]. In addition, the stage of patients' cancer was considered as inclusion criteria by Fernández-Lao et al., and was their study was carried out on subjects with cancer in stages I-IIIA [40,41]. Only the study by Serra-Añó et al. [44] considered the type of surgery the patients had undergone (only conservative/partial) when choosing study participants.

\subsection{Characteristics of the Interventions}

All of the studies had two comparison branches. The studies compared myofascial therapy with: educational sessions on healthy lifestyles, focusing on nutrition, relaxation techniques, and exercise, with advice on how to improve quality of life after cancer [40,41], with a standard physical therapy program and consistent placebo intervention with bilateral static hand placements on the upper body and arm $[42,45,46]$, with pulsed shortwave therapy [43], and with relaxing Swedish massage which avoided the affected area [47].

The types of myofascial interventions used, although all of them were manual interventions, varied among the studies. A myofascial induction protocol centered on the neck and shoulder following the Barnes approach $[40,41]$, trigger point treatments on upper limbs and adhesions in the pectoral muscle, cervical region, diaphragm, and scars [42,45,46], myofascial massage specific to the chest, thorax, and shoulder of the affected side [46], and myofascial release [43,44] were all used.

With regard to the number and length of sessions and the duration of the therapy, the studies were very heterogeneous. Fernández-Lao et al. conducted two 40-min sessions separated by an interval of two and three weeks $[40,41]$, two studies conducted two 30-min sessions per week for eight weeks [42,47] two conducted two 30-min sessions per week for 12 weeks, later reduced to one session per week $[45,46]$, one a 50 -min session per week for four weeks [44], and finally, one study conducted two 30-min sessions four weeks apart [43] (see Table 2).

\subsection{Outcome Measures}

\subsubsection{Primary Measures}

Pain: All but one of the studies evaluated pain or pain-related outcomes [41]. In the majority of cases, it was measured using a visual analog scale (VAS) [42-45,47]; in two of the studies, quantitative and qualitative aspects of pain were assessed using the McGill Pain Questionnaire [42,45]. Furthermore, three studies measured pain threshold with pressure from an algometer on different muscle points [40,42,46]. Pain was assessed using a scale from 0 to 30 [47], a scale from 0 to 10 [43,44], and a scale from 0 to 100 [42,46]. One study measured pain in the cervical spine, the affected limb and non-affected limb [43], and two measured pain in the shoulder, neck region, arm, armpit, trunk side and breast region $[42,46]$. The unit of measurement differed between the studies, as one used $\mathrm{kPa}$ [40], and the other two used $\mathrm{kg} / \mathrm{cm}^{2}[42,46]$.

Shoulder functionality: the majority of the studies measured functional status using the Disabilities of the Arm, Shoulder and Hand (DASH) scale [41,43-45]; for all of them, total scores were $0-100$, with a higher score indicating a greater disability. One study measured shoulder functionality on an unvalidated scale ranging from 0 to 40 , where 0 was no difficulty and 40 was severe difficulty [46]. 
Table 2. Intervention characteristics of the Myofascial Therapy Group.

\begin{tabular}{|c|c|c|c|c|c|c|}
\hline Author/Year & $\begin{array}{l}\text { N Therapeutic } \\
\text { Group }\end{array}$ & Type & $\begin{array}{c}\text { Time } \\
\text { Per Session }\end{array}$ & $\begin{array}{l}\text { Number of } \\
\text { Sessions }\end{array}$ & $\begin{array}{c}\text { Length of } \\
\text { Intervention }\end{array}$ & Observations \\
\hline $\begin{array}{l}\text { Fernández- } \\
\text { Lao et al. } \\
(2012)[40]^{*}\end{array}$ & 10 & $\begin{array}{l}\text { Myofascial release: the } \\
\text { patients received a } \\
\text { myofascial release } \\
\text { protocol which focused } \\
\text { on the neck and } \\
\text { shoulder area } \\
\text { following the Barnes } \\
\text { approach. } \\
\text { The protocol included } \\
\text { longitudinal strokes, } \\
\text { J-strokes, sustained } \\
\text { suboccipital pressure, } \\
\text { frontal bone } \\
\text { decompression and the } \\
\text { ear traction technique. }\end{array}$ & $\begin{array}{l}40 \text { min } \\
\text { (length } \\
\text { adapted to } \\
\text { the tissue } \\
\text { response of } \\
\text { the patient) }\end{array}$ & $\begin{array}{c}2 \text { sessions } \\
\text { separated by } \\
\text { a 3-week } \\
\text { interval }\end{array}$ & 5 weeks & $\mathrm{N} / \mathrm{A}$ \\
\hline $\begin{array}{l}\text { Fernández- } \\
\text { Lao et al. } \\
(2011)[41]^{*}\end{array}$ & 10 & $\begin{array}{l}\text { Myofascial release: } \\
\text { protocol which focused } \\
\text { on the neck and } \\
\text { shoulder area using the } \\
\text { Barnes approach. } \\
\text { The protocol included } \\
\text { longitudinal strokes, } \\
\text { J-strokes, sustained } \\
\text { suboccipital pressure, } \\
\text { frontal bone } \\
\text { decompression and the } \\
\text { ear traction technique. }\end{array}$ & $\begin{array}{l}40 \mathrm{~min} \\
\text { (length } \\
\text { adapted to } \\
\text { the tissue } \\
\text { response of } \\
\text { the patient) }\end{array}$ & $\begin{array}{c}2 \text { sessions } \\
\text { separated by } \\
2 \text { weeks }\end{array}$ & 4 weeks & $\begin{array}{l}80 \% \text { of the } \\
\text { patients } \\
\text { underwent } \\
\text { surgery at least } \\
12 \text { months } \\
\text { before the } \\
\text { intervention. }\end{array}$ \\
\hline $\begin{array}{l}\text { Groef et al. } \\
\text { (2017) [42] }\end{array}$ & 72 & $\begin{array}{l}\text { Standard physical } \\
\text { therapy program } \\
\text { (shoulder } \\
\text { mobilizations, pectoral } \\
\text { stretching and } \\
\text { relaxation, scar } \\
\text { massage, shoulder } \\
\text { exercise schemes) + } \\
\text { Myofascial therapy } \\
\text { consisting of manual } \\
\text { myofascial release } \\
\text { techniques on (1) active } \\
\text { myofascial trigger } \\
\text { points in the upper } \\
\text { limb area and (2) } \\
\text { myofascial adhesions } \\
\text { in the pectoral, axillary } \\
\text { and cervical regions, } \\
\text { diaphragm and scars. }\end{array}$ & $\begin{array}{l}\text { Physical } \\
\text { therapy } \\
\text { program: } \\
30 \text { min } \\
\text { Myofascial } \\
\text { release: } \\
30 \mathrm{~min}\end{array}$ & $\begin{array}{c}2 \text { sessions a } \\
\text { week }\end{array}$ & 8 weeks & $\begin{array}{l}\text { The patients } \\
\text { were asked to } \\
\text { perform } \\
\text { exercises twice } \\
\text { a day at home. } \\
\text { Myofascial } \\
\text { interventions } \\
\text { were performed } \\
\text { from } 2 \text { to } \\
4 \text { months after } \\
\text { surgery. }\end{array}$ \\
\hline $\begin{array}{c}\text { Castro- } \\
\text { Martín et al. } \\
(2016)[43]\end{array}$ & 21 & $\begin{array}{l}\text { The patients received a } \\
\text { fascial relaxation } \\
\text { intervention which } \\
\text { focused on the upper } \\
\text { limb area, using the } \\
\text { Pilat approach. }\end{array}$ & $\begin{array}{l}30 \mathrm{~min} \\
\text { (length } \\
\text { adapted to } \\
\text { the tissue } \\
\text { response of } \\
\text { the patient) }\end{array}$ & $\begin{array}{c}2 \text { sessions } \\
\text { separated by } \\
\text { a } 4 \text {-week } \\
\text { interval }\end{array}$ & 4 weeks & $\begin{array}{l}60 \% \text { of patients } \\
\text { received } \\
\text { myofascial } \\
\text { intervention in } \\
\text { less than } \\
12 \text { months after } \\
\text { surgery. }\end{array}$ \\
\hline
\end{tabular}


Table 2. Cont.

\begin{tabular}{|c|c|c|c|c|c|c|}
\hline Author/Year & $\begin{array}{l}\text { N Therapeutic } \\
\text { Group }\end{array}$ & Type & $\begin{array}{c}\text { Time } \\
\text { Per Session }\end{array}$ & $\begin{array}{c}\text { Number of } \\
\text { Sessions }\end{array}$ & $\begin{array}{c}\text { Length of } \\
\text { Intervention }\end{array}$ & Observations \\
\hline $\begin{array}{l}\text { Serra-Añó et al. } \\
\text { (2018) [44] }\end{array}$ & 13 & $\begin{array}{l}\text { The applied treatment } \\
\text { was based on the Pilat } \\
\text { technique. Four } \\
\text { maneuvers were } \\
\text { selected for the } \\
\text { perinodal and upper } \\
\text { thoracic region. They } \\
\text { were applied in the } \\
\text { following order: } \\
\text { sterno-pectoral, global } \\
\text { pectoral, pectoral and } \\
\text { subscapular. }\end{array}$ & $50 \mathrm{~min}$ & $\begin{array}{c}1 \text { session a } \\
\text { week }\end{array}$ & 4 weeks & $\begin{array}{c}\text { The } \\
\text { intervention } \\
\text { was carried out } \\
\text { at least } \\
4 \text { months after } \\
\text { surgery. }\end{array}$ \\
\hline $\begin{array}{l}\text { Groef et al. } \\
(2017)[45,46]\end{array}$ & $25(2)$ & $\begin{array}{l}\text { Standard physical } \\
\text { therapy program } \\
\text { (shoulder } \\
\text { mobilizations, pectoral } \\
\text { stretching and } \\
\text { relaxation, scar } \\
\text { massage, shoulder } \\
\text { exercise schemes) + } \\
\text { Myofascial release in } \\
\text { (1) active trigger points } \\
\text { of the upper limbs and } \\
\text { in (2) myofascial } \\
\text { adhesions of the } \\
\text { pectoralis, axillary and } \\
\text { cervical regions, } \\
\text { diaphragm and scars. }\end{array}$ & $\begin{array}{l}\text { Physical } \\
\text { therapy } \\
\text { program: } \\
30 \text { min } \\
\text { Myofascial } \\
\text { release: } \\
30 \text { min }\end{array}$ & $\begin{array}{l}2 \text { sessions a } \\
\text { week } \\
\text { (week 1-8) } \\
1 \text { session a } \\
\text { week } \\
\text { (week 9-12) }\end{array}$ & 12 weeks & $\begin{array}{c}\text { The } \\
\text { intervention } \\
\text { was at least } \\
3 \text { months after } \\
\text { radiation } \\
\text { therapy and } \\
3 \text { years after } \\
\text { surgery. }\end{array}$ \\
\hline $\begin{array}{l}\text { Massingill et al. } \\
\text { (2018) [47] }\end{array}$ & 10 & $\begin{array}{l}\text { The participants of the } \\
\text { intervention received } \\
\text { myofascial massage } \\
\text { specifically for the } \\
\text { chest, thorax and } \\
\text { shoulder on the } \\
\text { affected side. The } \\
\text { massages of the } \\
\text { intervention included } \\
\text { the following } \\
\text { techniques: skin } \\
\text { gliding (variable length } \\
\text { of time), J-stroke } \\
\text { (2-3 min), vertical } \\
\text { strokes (2-3 min), } \\
\text { strumming ( } 2-3 \text { min), } \\
\text { fascial stretching } \\
\text { (3-5 min), circular } \\
\text { friction (1 to } 2 \text { min), } \\
\text { deep fascial release } \\
\text { (3-5 min), arm pull } \\
\text { (60 s on each arm), } \\
\text { lateral latissimus dorsi } \\
\text { stretch ( } 3 \text { to } 5 \text { min) and } \\
\text { twisting ( } 3 \text { min). }\end{array}$ & $30 \mathrm{~min}$ & $\begin{array}{c}2 \text { sessions a } \\
\text { week }\end{array}$ & 8 weeks & $\begin{array}{c}\text { The } \\
\text { intervention } \\
\text { began between } \\
3 \text { and } \\
18 \text { months after } \\
\text { surgery. }\end{array}$ \\
\hline
\end{tabular}

Abbreviations: DN, dry needling; MTrP, myofascial trigger point; NR, not reported; TP, trigger point. * These publications belong to the same study, but evaluate different outcomes. 


\subsubsection{Secondary Measures}

Shoulder mobility: Three studies evaluated shoulder mobility using manual goniometry in degrees [43-45]. One study measured flexion, abduction and active external and internal rotation on the affected and non-affected side [43]. Another also took into account extension and adduction but only of the affected side [44], and another measured the flexion and abduction, and the upward scapular rotation [45].

Mood state: Two studies evaluated the mood states of participants with the Profile of Mood States (POMS) scale [41,43]. Another study evaluated depression with the Patient-9 Health Questionnaire (PHQ-9), and one study linked participants' saliva flow rate and the amount of immunoglobulin A and cortisol to stress levels and the patients' attitude towards the intervention.

Quality of life: Five of the eight chosen studies evaluated participants' quality of life [42,44-47], although the scales that were used varied among the studies. The most commonly-used scale was the SF-36 [42,45,46], although one study used the short version, SF-12 [47], and another one used the Functional Assessment of Cancer Therapy-Breast (FACT-B + 4) scale.

\subsection{Follow-Up}

More than half the studies limited their follow-up to immediately following the intervention [40,41,43,44,47]. Just two studies followed-up between $\geq 6$ months and $\leq 9$ months $[45,46]$ and three studies also followed-up long-term ( $>9$ months) $[42,45,46]$.

\subsection{Risk of Bias in the Studies Included}

The results of the risk of bias (RoB) analysis for the individual studies are summarized in Figures 2 and 3. In total, approximately one-third of the studies were considered to have a moderate RoB.

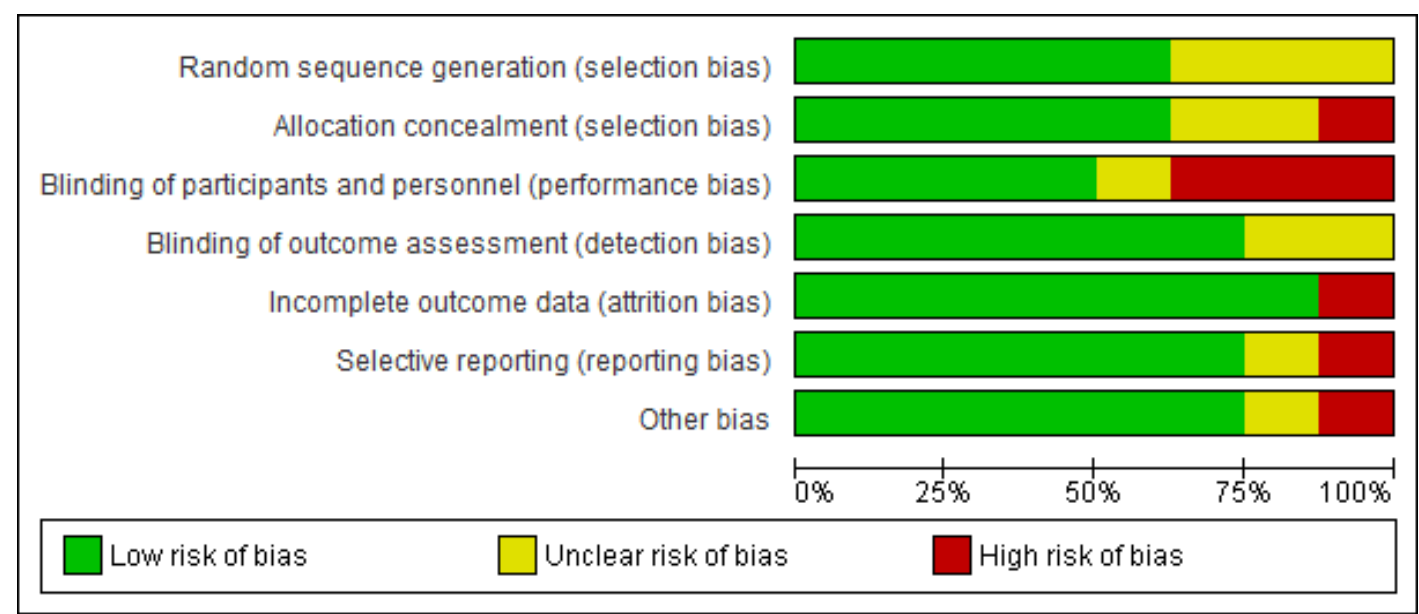

Figure 2. Risk of bias graph: review authors' judgements about each risk of bias item presented as percentages across all included studies. 


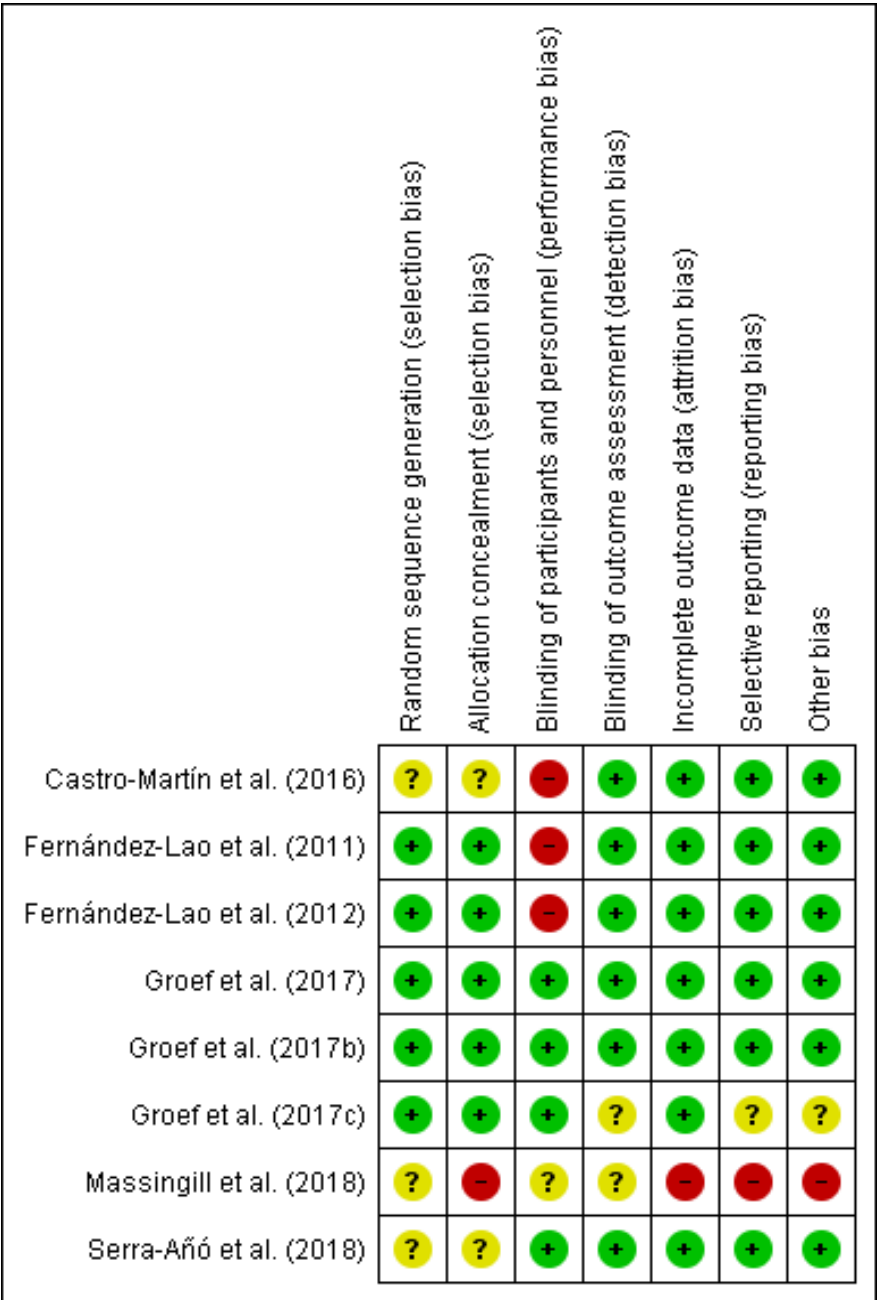

Figure 3. Risk of bias summary: review authors' judgements about each risk of bias item for each included study.

\subsection{Effects of the Interventions}

3.8.1. Myofascial Therapy vs. Placebo Treatment or Other Intervention at Post-Immediate

Figures $4-7$ show the estimated primary effect size (4-8 weeks post-treatment) of the intervention with myofascial therapy alone or combined, compared to an inactive control, placebo treatment or other intervention with physical therapy for the outcomes of pain intensity, functionality, and range of motion in flexion and abduction.

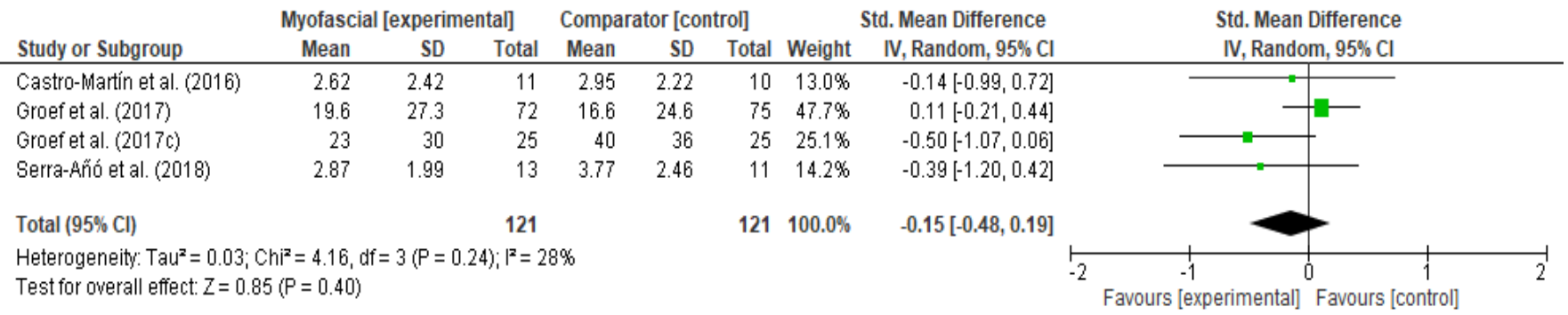

Figure 4. Forest plot of comparison: 1 Myofascial therapy vs. placebo treatment or other intervention, outcome: 1.1 Pain Intensity-Post immediate. 


\begin{tabular}{|c|c|c|c|c|c|c|c|c|c|c|}
\hline \multirow[b]{2}{*}{ Study or Subgroup } & \multicolumn{3}{|c|}{ Myofascial [experimental] } & \multicolumn{3}{|c|}{ Comparator [control] } & \multicolumn{2}{|r|}{ Std. Mean Difference } & \multirow{2}{*}{$\begin{array}{l}\text { Std. Mean Difference } \\
\text { IV, Random, } 95 \% \mathrm{Cl}\end{array}$} & \\
\hline & Mean & SD & Total & Mean & SD & Total & Weight & IV, Random, $95 \% \mathrm{Cl}$ & & \\
\hline Groef et al. (2017) & 56 & 17 & 72 & 59 & 22 & 75 & $66.6 \%$ & $-0.15[-0.48,0.17]$ & -日1 & \\
\hline Groef et al. (2017c) & 30 & 17 & 25 & 33 & 21 & 25 & $22.7 \%$ & $-0.15[-0.71,0.40]$ & & \\
\hline Serra-Añó et al. (2018) & 20.69 & 16.2 & 13 & 25.37 & 11 & 11 & $10.7 \%$ & $-0.32[-1.13,0.49]$ & & \\
\hline Total $(95 \% \mathrm{Cl})$ & & & 110 & & & 111 & $100.0 \%$ & $-0.17[-0.43,0.09]$ & & \\
\hline $\begin{array}{l}\text { Heterogeneity: } \operatorname{Tau}^{2}=0 \text {. } \\
\text { Test for overall effect: } Z\end{array}$ & $\begin{array}{l}\mathrm{Chi}^{2}=0.1 \\
.26(\mathrm{P}=0 .\end{array}$ & $=2(1$ & $93) ; 1^{2}$ & $=0 \%$ & & & & & $\begin{array}{lcc} & 1 & \\
-2 & -1 & 0 \\
& \text { Favours [experimental] } & \text { Favours [co }\end{array}$ & $\begin{array}{c}1 \\
\text { ontrol] }\end{array}$ \\
\hline
\end{tabular}

Figure 5. Forest plot of comparison: 1 Myofascial therapy vs. placebo treatment or other intervention, outcome: 1.2 Functionality-Post-immediate.

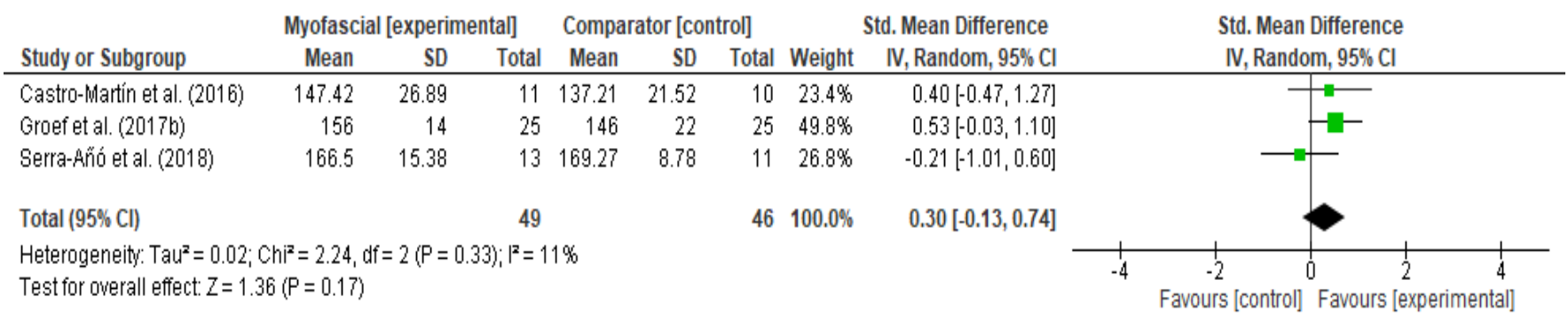

Figure 6. Forest plot of comparison: 1 Myofascial therapy vs. placebo treatment or other intervention, outcome: 1.3 Range of motion-Flexion-Post immediate.

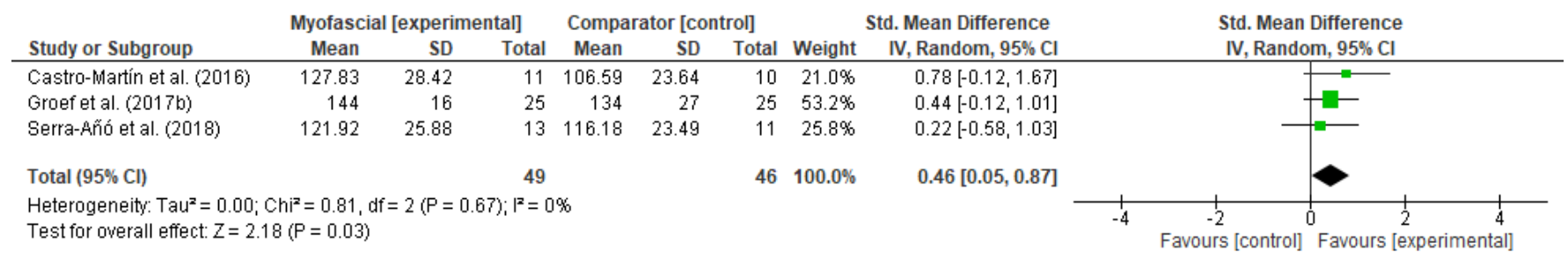

Figure 7. Forest plot of comparison: 1 Myofascial therapy vs. placebo treatment or other intervention, outcome: 1.4 Range of motion-Abduction-Post-immediate.

\section{Pain Intensity}

This sub-analysis included four trials [42-45] with 242 participants. No significant differences were observed between the effects of myofascial therapy alone or in combination with a standard physical therapy program and placebo intervention or a standard physical therapy program (Figure 4 . SMD $-0.15,95 \% \mathrm{CI}-0.48$ to $0.19, \mathrm{I}^{2}=28 \%$ ).

\section{Functionality}

Meta-analyses of three studies [42,44,46] with 121 participants revealed that there were no statistically significant differences between the two groups on post-immediate functionality (Figure 5, SMD $-0.17,95 \% \mathrm{CI}-0.43$ to $0.09, \mathrm{I}^{2}=0 \%$ ). However, the results were in favor of the group treated with myofascial therapy.

\section{Range of motion}

This subgroup involved 3 trials [43-45] covering 95 participants. Meta-analysis result demonstrated that myofascial therapy does not have a greater statistically significant immediate effect on range of motion in flexion (Figure 6, SMD 0.30, 95\% CI -0.13 to 0.74, $\mathrm{I}^{2}=11 \%$ ) than a placebo treatment or other intervention. However, a statistically significant result was observed for shoulder range of motion in abduction in favor of the experimental group (Figure 7, SMD $0.46,95 \%$ CI 0.05 to $0.87, \mathrm{I}^{2}=0 \% ; p=0.03$ ).

Low-moderate quality evidence indicates that myofascial therapy does not have a greater statistically significant immediate effect on pain intensity, functionality, and range of motion in flexion than a placebo treatment or other intervention at post-immediate 
follow up. The estimations of the primary effect show small or null statistically significant heterogeneity between the effect size of the studies included in this analysis; the statistic $\mathrm{I}^{2}$ ranged from $0 \%$ "low threshold" and $28 \%$ "low-moderate threshold".

\subsubsection{Myofascial Therapy vs. Placebo Treatment or Minimal Intervention at} Post-Immediate

Figures $8-10$ show the results of the estimated primary and secondary effects as forest-plots grouped separately by outcome measure type, immediately following the intervention with myofascial techniques.

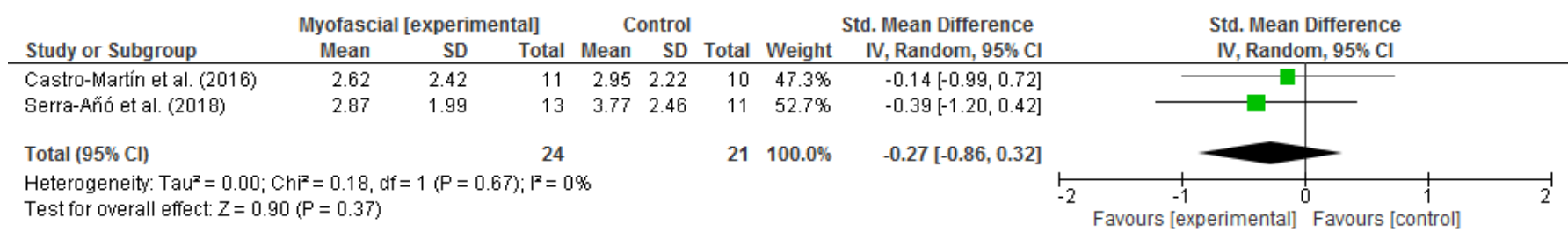

Figure 8. Forest plot of comparison: 2 Myofascial therapy vs. placebo treatment or minimal intervention, outcome: 2.1 Pain Intensity-Post immediate.

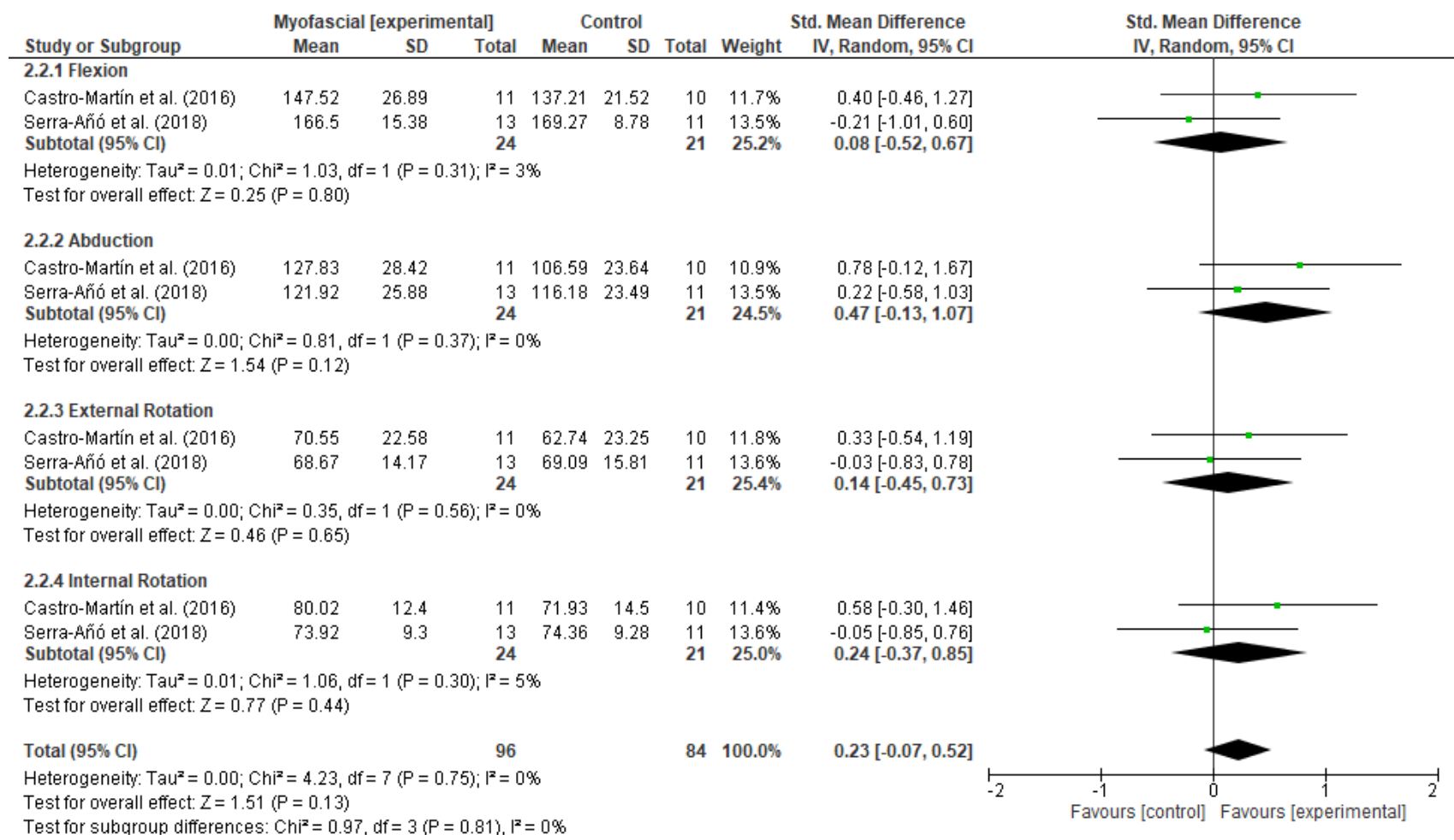

Figure 9. Forest plot of comparison: 2 Myofascial therapy vs. placebo treatment or minimal intervention, outcome: 2.2 Range of motion-Post-immediate. 


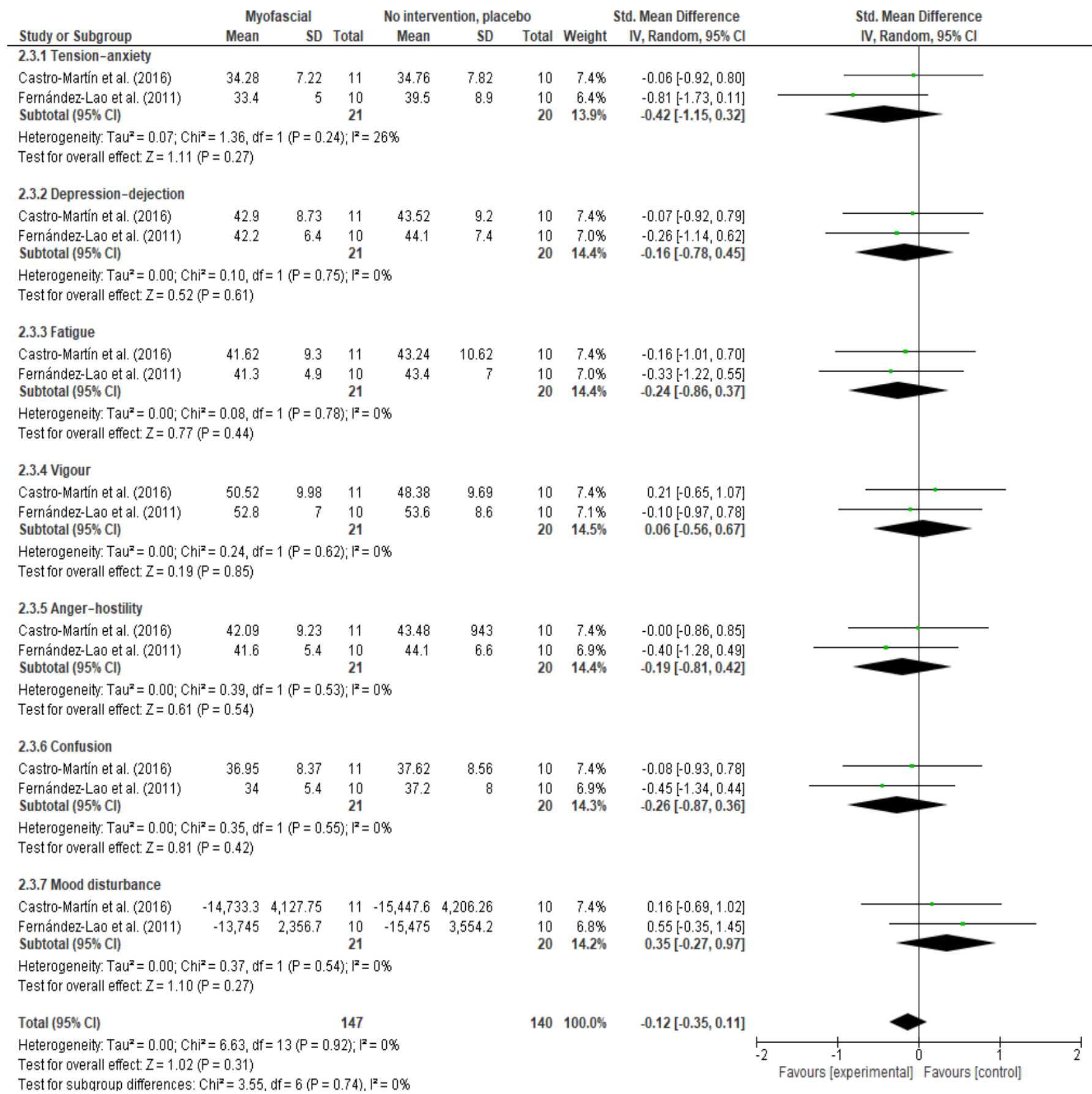

Figure 10. Forest plot of comparison: 2 Myofascial therapy vs. placebo treatment or minimal intervention, outcome: 2.3 Mood States-Post-immediate.

\section{Pain intensity}

Meta-analyses of two studies [43,44] with 45 participants, demonstrated that the effect of myofascial therapy was no superior to placebo treatment nor minimal intervention for alleviating post-immediate pain intensity (Figure $8, \mathrm{SMD}-0.27,95 \% \mathrm{CI}-0.86$ to $0.32, \mathrm{I}^{2}=0 \%$ ).

\section{Range of motion}

Meta-analyses of two studies [43,44] showed that range of motion in flexion, abduction, internal and external rotation (Figure 9, SMD $0.23,95 \%$ CI -0.07 to $0.52, \mathrm{I}^{2}=0 \%$ ) was similar between the two groups. 


\section{Mood state}

This sub-analysis of two trials [41,43] with 41 participants did not obtained statistically significant differences between groups (Figure 10 , SMD $-0.12,95 \% \mathrm{CI}-0.35$ to $0.11, \mathrm{I}^{2}=0 \%$ ).

Low-quality evidence indicates that applying myofascial techniques does not have a greater immediate effect on pain intensity, range of motion in flexion, abduction, internal and external rotation, and mood state, than a placebo or a minimal intervention. For the three outcome measures, the $\mathrm{I}^{2}$ statistic was $0 \%$, null statistic heterogeneity.

3.8.3. Myofascial Technique (Physical Therapy and Myofascial Therapy) vs. Other Interventions (Physical Therapy and Placebo) at Post-Immediate, Medium Term and Long Term

Figures 11-19 show the results as forest-plots grouped by primary and secondary effects, and separated by the duration of the effects after completing the myofascial intervention.

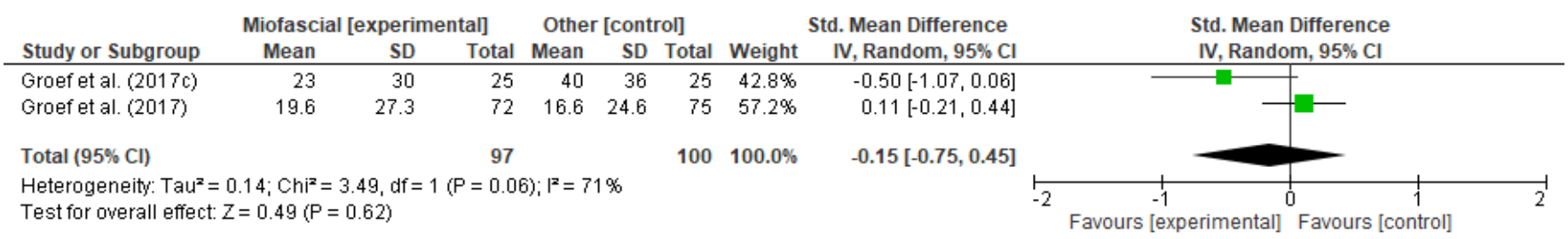

Figure 11. Forest plot of comparison: 3 Myofascial therapy (physical therapy and myofascial therapy) vs. Other intervention (physical therapy and placebo), outcome: 3.1 Pain Intensity-Post immediate.

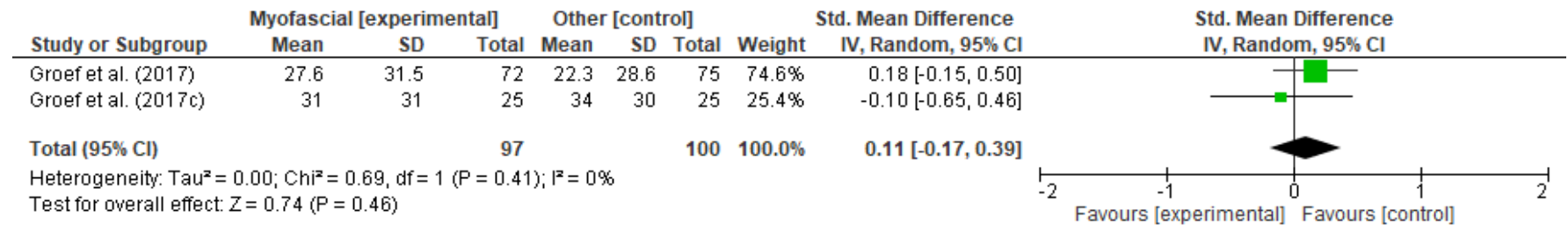

Figure 12. Forest plot of comparison: 3 Myofascial therapy (physical therapy and myofascial therapy) vs. Other intervention (physical therapy and placebo), outcome: 3.2 Pain Intensity-Medium term.

\begin{tabular}{|c|c|c|c|c|c|c|c|c|c|c|}
\hline \multirow[b]{2}{*}{ Study or Subgroup } & \multicolumn{3}{|c|}{ Myofascial [experimental] } & \multicolumn{3}{|c|}{ Other [control] } & \multirow[b]{2}{*}{ Weight } & \multirow{2}{*}{$\begin{array}{l}\text { Std. Mean Difference } \\
\text { IV, Random, } 95 \% \mathrm{Cl}\end{array}$} & \multirow{2}{*}{\multicolumn{2}{|c|}{$\begin{array}{l}\text { Std. Mean Difference } \\
\text { IV, Random, } 95 \% \mathrm{Cl}\end{array}$}} \\
\hline & Mean & SD & Total & Mean & SD & Total & & & & \\
\hline Groef et al. (2017) & 20.8 & 26.2 & 72 & 25.1 & 29.6 & 75 & $74.8 \%$ & $-0.15[-0.48,0.17]$ & . & \\
\hline Groef et al. (2017c) & 33 & 30 & 25 & 43 & 28 & 25 & $25.2 \%$ & $-0.34[-0.90,0.22]$ & & \\
\hline Total $(95 \% \mathrm{Cl})$ & & & 97 & & & 100 & $100.0 \%$ & $-0.20[-0.48,0.08]$ & & \\
\hline $\begin{array}{l}\text { Heterogeneity: Tau } \\
\text { Test for overall effect }\end{array}$ & $\begin{array}{l}.00 ; \mathrm{Chi}^{2}= \\
=1.40(\mathrm{P}\end{array}$ & $d f=$ & 0.57 & $; 1^{2}=$ & & & & $\mathfrak{-}_{-2}$ & $\begin{array}{ccc} & 1 & \\
& -1 & 0 \\
& \text { Favours [experimental] } & \\
\text { Favours [o }\end{array}$ & ntrol] \\
\hline
\end{tabular}

Figure 13. Forest plot of comparison: 3 Myofascial therapy (physical therapy and myofascial therapy) vs. Other intervention (physical therapy and placebo), outcome: 3.3 Pain Intensity-Long term.

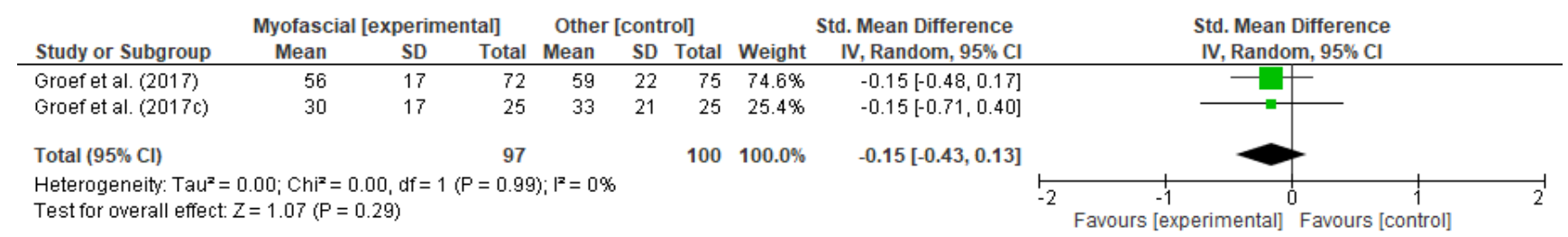

Figure 14. Forest plot of comparison: 3 Myofascial Therapy (physical therapy and myofascial therapy) vs. Other intervention (physical therapy and placebo), outcome: 3.4 Functionality-Post immediate. 


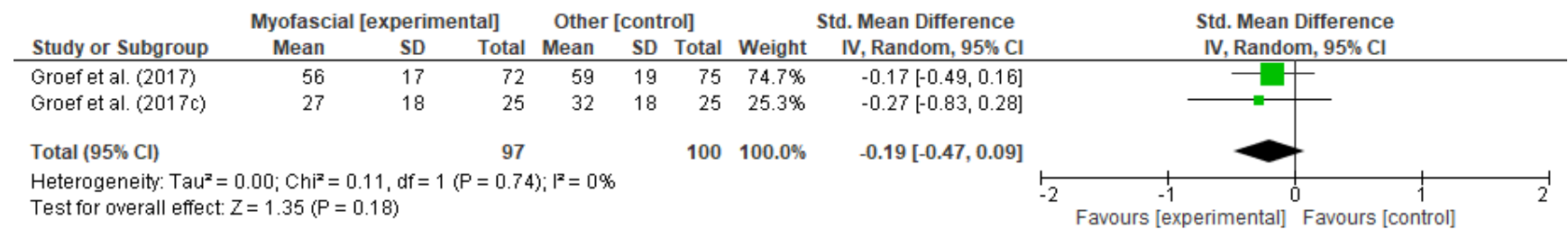

Figure 15. Forest plot of comparison: 3 Myofascial therapy (physical therapy and myofascial therapy) vs. Other intervention (physical therapy and placebo), outcome: 3.5 Functionality-Medium term.

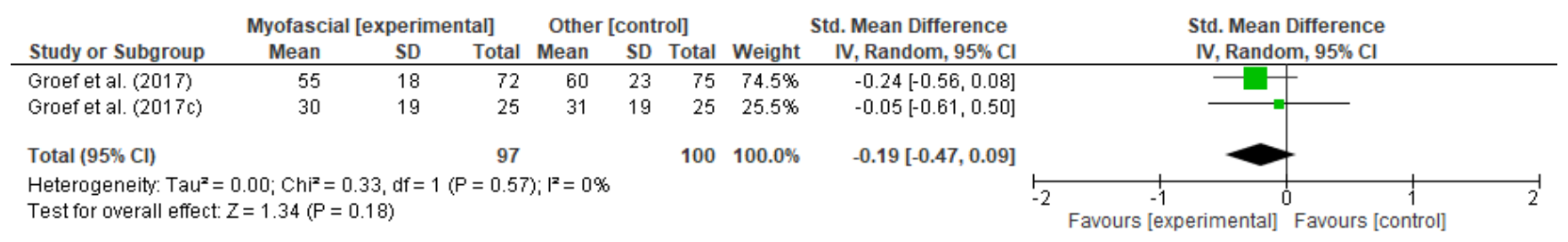

Figure 16. Forest plot of comparison: 3 Myofascial therapy (physical therapy and myofascial therapy) vs. Other intervention (physical therapy and placebo), outcome: 3.6 Functionality-Long term.

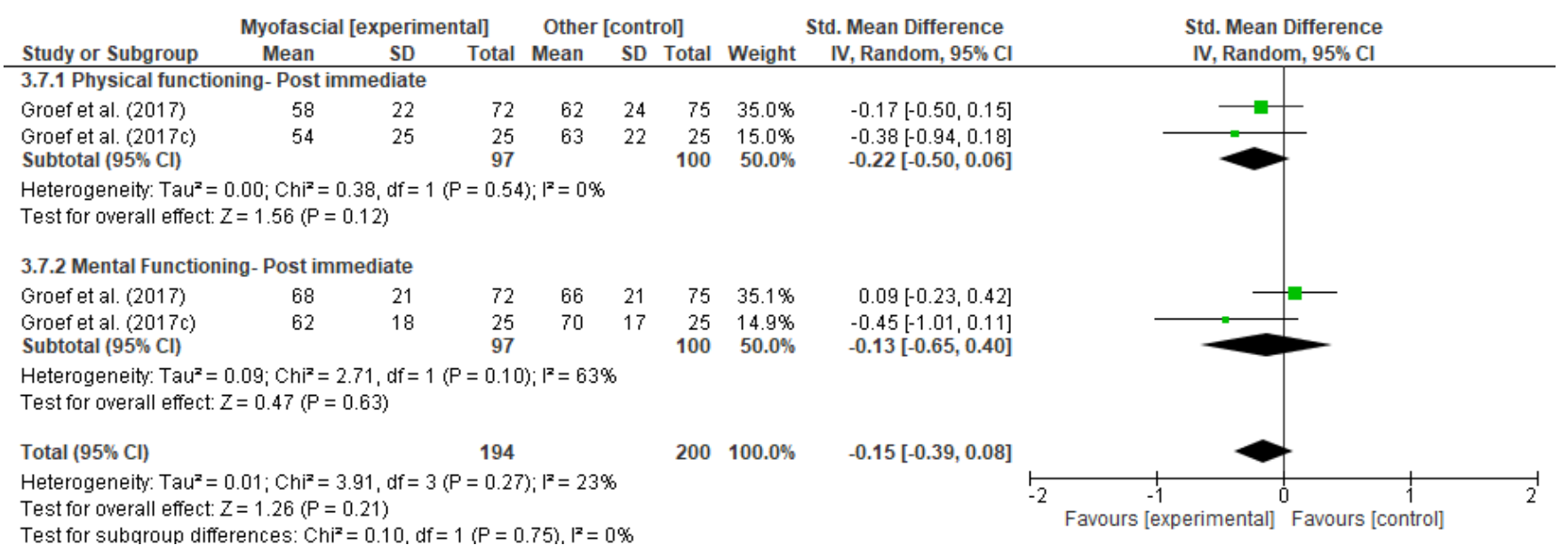

Figure 17. Forest plot of comparison: 3 Myofascial therapy (physical therapy and myofascial therapy) vs. Other intervention (physical therapy and placebo), outcome: 3.7 Quality of life-Post immediate.

\begin{tabular}{|c|c|c|c|c|c|c|c|c|c|c|}
\hline \multirow[b]{2}{*}{ Study or Subgroup } & \multicolumn{3}{|c|}{ Experimental } & \multicolumn{3}{|c|}{ Control } & \multicolumn{2}{|r|}{ Std. Mean Difference } & \multirow{2}{*}{\multicolumn{2}{|c|}{$\begin{array}{l}\text { Std. Mean Difference } \\
\text { IV, Random, } 95 \% \mathrm{Cl}\end{array}$}} \\
\hline & Mean & SD & Total & Mean & SD & Total & Weight & IV, Random, $95 \% \mathrm{Cl}$ & & \\
\hline \multicolumn{11}{|c|}{ 3.8.3 Physical functioning- Mid term (6-9 months) } \\
\hline Groef et al. (2017) & 57 & 23 & 72 & 61 & 25 & 75 & $35.0 \%$ & $-0.17[-0.49,0.16]$ & & \\
\hline Groef et al. (2017c) & 65 & 24 & 25 & 58 & 24 & 25 & $15.0 \%$ & $0.29[-0.27,0.84]$ & & \\
\hline Subtotal $(95 \% \mathrm{Cl})$ & & & 97 & & & 100 & $50.0 \%$ & $0.00[-0.43,0.43]$ & & \\
\hline \multicolumn{11}{|c|}{$\begin{array}{l}\text { Heterogeneity: } \text { Tau }^{2}=0.05 ; \mathrm{Chi}^{2}=1.89, \mathrm{df}=1(P=0.17) ;\left.\right|^{2}=47 \% \\
\text { Test for overall effect: } Z=0.01(P=0.99)\end{array}$} \\
\hline \multicolumn{11}{|c|}{ 3.8.4 Mental functioning-Mid term (6-9 months) } \\
\hline Groef et al. (2017) & 60 & 16 & 72 & 65 & 20 & 75 & $34.9 \%$ & $-0.27[-0.60,0.05]$ & & \\
\hline $\begin{array}{l}\text { Groef et al. }(2017 \mathrm{c}) \\
\text { Subtotal }(95 \% \mathrm{Cl})\end{array}$ & 69 & 20 & $\begin{array}{l}25 \\
97\end{array}$ & 66 & 20 & $\begin{array}{r}25 \\
100\end{array}$ & $\begin{array}{l}15.1 \% \\
50.0 \%\end{array}$ & $\begin{array}{r}0.15[-0.41,0.70] \\
-0.13[-0.52,0.27]\end{array}$ & & \\
\hline \multicolumn{11}{|c|}{$\begin{array}{l}\text { Heterogeneity: } \operatorname{Tau}^{2}=0.04 ; \mathrm{Chi}^{2}=1.65, \mathrm{df}=1(\mathrm{P}=0.20) ; \mathrm{I}^{2}=39 \% \\
\text { Test for overall effect: } Z=0.62(P=0.53)\end{array}$} \\
\hline Total $(95 \% \mathrm{Cl})$ & & & 194 & & & 200 & $100.0 \%$ & $-0.09[-0.32,0.14]$ & & \\
\hline \multicolumn{9}{|c|}{$\begin{array}{l}\text { Heterogeneity: } \text { Tau }^{2}=0.01 ; \mathrm{Chi}^{2}=3.87, \mathrm{df}=3(\mathrm{P}=0.28) ; \mathrm{I}^{2}=22 \% \\
\text { Test for overall effect: } \mathrm{Z}=0.74(\mathrm{P}=0.46) \\
\text { Test for subqroup differences: } \mathrm{Ch}^{2}=0.18, \mathrm{df}=1(\mathrm{P}=0.67), \mathrm{I}^{2}=0 \%\end{array}$} & 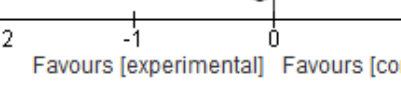 & introl] \\
\hline
\end{tabular}

Figure 18. Forest plot of comparison: 3 Myofascial therapy (physical therapy and myofascial therapy) vs. Other intervention (Physical therapy and placebo), outcome: 3.8 Quality of life-Medium term. 


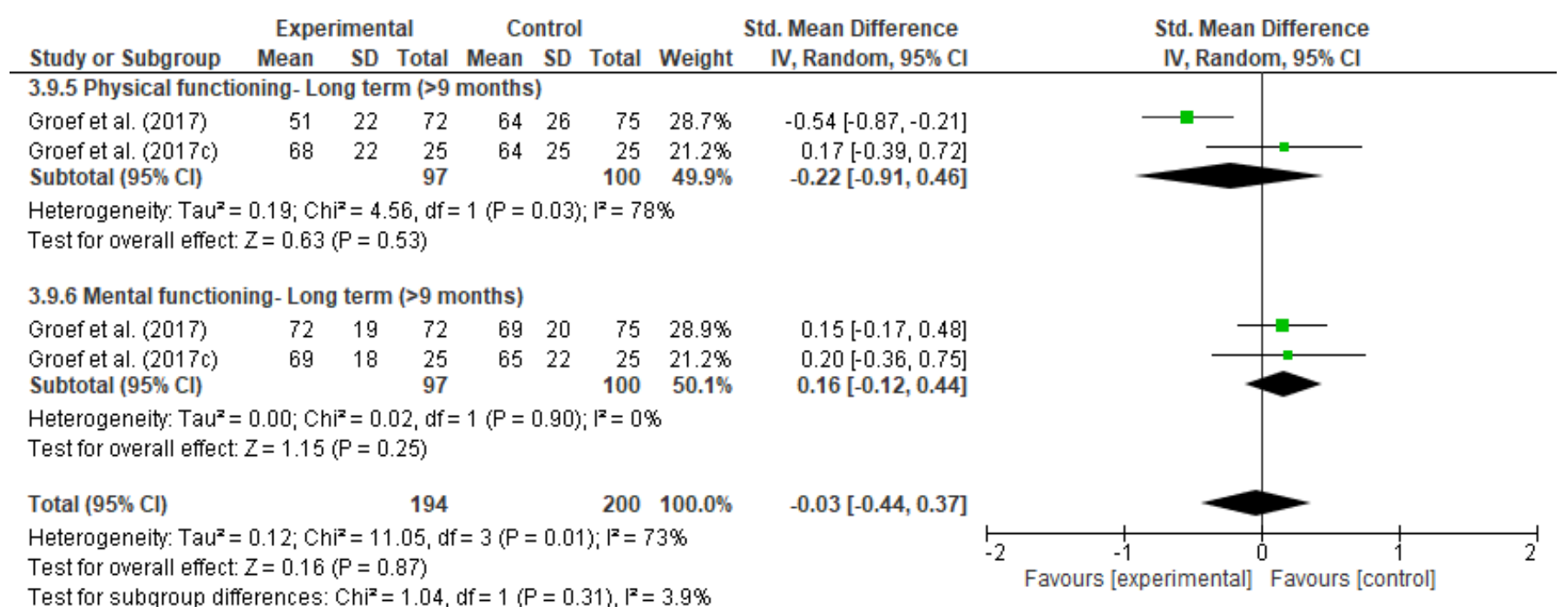

Figure 19. Forest plot of comparison: 3 Myofascial therapy (physical therapy and myofascial therapy) vs. Other intervention (physical therapy and placebo), outcome: 3.9 Quality of life-Long term.

\section{Pain Intensity}

This meta-analysis included two studies and 197 participants [42,46]. The point estimates for the SMD between the groups varied from 0.11 to 0.20 (Figures 11-13. 95\% IC; $\mathrm{I}^{2}=0 \%$ to $71 \%$ ) in the short-, medium-, and long-term; in all cases. The results of this meta-analysis indicate that there is not a statistically significant effect for pain intensity in favor of myofascial therapy over other types of interventions.

\section{Functionality}

Two studies with 197 participants were meta-analyzed for shoulder functionality [42,46]. The estimates varied from 0.15 to 0.19 (SMD) (Figures $14-16.95 \%$ IC; $\mathrm{I}^{2}=0 \%$ ) and although all of them favored the myofascial therapy, their differences were not statistically significant.

\section{Quality of life}

The result of the meta-analysis of two studies [42,46] demonstrated there were no statistically significant differences between the two groups for quality of life at any time (Figures 17-19), grouped estimates ranged from 0.03 to 0.15 (SMD) (95\% IC; $\mathrm{I}^{2}=22 \%$ to $73 \%$ ).

Moderate-high quality evidence indicates that myofascial therapy has no greater immediate, medium- and long-term effect on pain intensity, functionality, and quality of life than other forms of intervention.

The grouped estimates show little statistical heterogeneity among the studies' effect sizes. Of the six comparisons of pain and disability, five showed a null $\mathrm{I}^{2}$ statistic, only immediate post-treatment pain was above the 'high' threshold of $75 \%$.

\section{Discussion}

\subsection{Summary of Evidence}

We set out to conduct a unique, up-to-date review on the impact of myofascial therapy on breast cancer survivors. We found 8 published RCTs that evaluated the effects of myofascial therapy on these patients, although two studies could not be meta-analyzed. The study by Massingill et al. [47], could not be analyzed in the meta-analysis because of incomplete data in the results, and that of Groef et al. [45], presented duplicate results that were published in another of the studies included. Ultimately, for the qualitative analysis, six publications were considered, including five studies (as those publications by Fernández-Lao et al. [40,41] shared the same participants). Thus, a reduced number of patients than previously mentioned, 262 participants total, were included. 
In general, we found that interventions with myofascial therapy as the sole intervention or combined with physical therapy, do not generate, with low or moderate-quality proof, a significant improvement on pain intensity, functionality, range of motion and mood state in female survivors of breast cancer compared to an inactive control group or placebo or in comparison with other interventions.

There were greater general effects in favor of myofascial therapy than other controls/interventions, but the subgroup analyses revealed inconsistent, insignificant results. Only the range of motion in abduction showed statistical significance in favor of the experimental group. Here, myofascial therapy is at least equivalent to other forms of intervention.

Several factors should be considered when interpreting our findings for clinical recommendation and implementation. Although there was no statistical significance, all of the studies individually reported a clinically relevant improvement in favor of the experimental group with myofascial intervention. The effectiveness of myofascial therapy is unclear because the subgroup analyses were hampered by the small number of studies that included the same outcome measures and follow-up beyond immediately following the intervention. Very few studies reported comparable estimates regarding secondary outcome measures to calculate the effect of using myofascial therapy.

\subsection{Agreements or Disagreements with Other Studies or Reviews}

Myofascial therapy and its effect on certain populations has been briefly described in literature. Other meta-analyses that have attempted to demonstrate the efficacy of myofascial therapy have also faced the challenge of only finding articles of low methodological quality, and as a result, a small number of articles are included in the meta-analysis. In 2016, Webb and colleagues [48] did not find conclusive results after their meta-analysis about the efficacy of myofascial therapy on joint range of motion and perceived pain. A recently-published article also obtained outcomes that tend towards the statistical significance of myofascial techniques for the improvement of joint range of motion, without these generating a clinically relevant change [49]. Our article correlates with this article, as obtaining statistical significance in the improvement of the range of motion in shoulder abduction reaffirms myofascial therapy as an effective technique in the improvement of this specific variable. Additionally, regarding survivors of breast cancer, other systematic reviews have been carried out with meta-analyses using the generic term "manual therapy", which encompasses myofascial therapy. In the review carried out by Pinheiro and colleagues (2019), manual therapy does prove to be effective to decrease musculoskeletal pain [50]. However, this author could only include five articles in their meta-analysis, again, due to the limiting characteristics of the trials carried on manual therapy and cancer. These results are contradictory to those found in the review by Groef et al. (2015), that when analyzing the effectiveness of various postoperative physical therapy modalities, including myofascial therapy for the treatment of pain and range of motion of the shoulder in breast cancer, reported that to date, no RCT had reported on the effectiveness of myofascial therapy started in the postoperative phase after breast cancer treatment [30]. Despite the differences found regarding pain, our findings showed no improvement using myofascial therapy as opposed to other therapies on quality of life, which is consistent with the findings obtained in the review by Pinheiro and colleagues (2019) [50].

Nevertheless, despite not obtaining clear, insightful results in recent years on the clinical evidence of manual therapy and, thus, myofascial therapy, these techniques continue to be prescribed as treatment for pain management in cancer patients [51], and also for addressing other symptoms such as anxiety or altered mood states, due to their non-invasive nature and the absence of negative side effects. Myofascial therapy, described by Pilat in 2003 [52], is a relatively recent technique, which, despite its frequent use in clinical physical therapy, has not been explored deeply or frequently enough to test its effects on different populations. Thereby, as shown in this review, there are many different approaches of myofascial therapy. In order to understand whether myofascial therapy is a useful rehabil- 
itation approach for this population, these differences should also be objective of future randomized controlled trials, to check the superiority of specific methods among others.

\section{Study Limitations}

Our review was limited by the small number published trials to date, the impossibility of blinding participants and physical therapists, the small sample size, and nonhomogeneous follow-up of the included studies.

The outcomes for pain intensity, functionality, and range of motion should be considered key to evaluating the effects of myofascial therapy on the study population, as these factors are the main causes of the emotional burden of the disease [53]. Many of the included studies did not report these results and, when reported, they were measured at different time periods. The lack of standardization measurements makes quantitative synthesis of the body of evidence problematic.

The inconsistent nature of data collection and reporting made it difficult to draw conclusions regarding medium- and long-term results, as half of the studies only collected data immediately following the intervention.

For example, in the comparison between myofascial therapy versus a placebo or minimal intervention, the studies reported on the outcome measures of pain, range of motion and mood state only immediately following treatment. The fact that this data was not reported in a comparable manner over time limits our ability to estimate the true effect of myofascial therapy on a critical outcome.

\section{Conclusions}

While our subgroup analyses show non-significance between groups, the results are inconclusive. The choice of myofascial therapy over other control groups with/without intervention for breast cancer survivors is likely to result in a positive effect on pain intensity, functionality, and range of motion. Myofascial therapy is also likely to have a beneficial effect on quality of life and mood state outcomes. However, given the results obtained, it would seem that there is little to gain from referring these patients to myofascial treatment. Despite this, the volume of evidence is small and additional similar studies are likely to greatly change the estimation of the effectiveness of myofascial therapy versus inactive controls, placebo, or other physical therapy interventions. Future studies are needed to confirm whether myofascial therapy is useful or not to man-age breast cancer survivors' sequelae.

Author Contributions: Conceptualization: I.C.L.-P., L.O.-C., M.M.C.-P.; data curation: I.C.L.-P.; formal analysis: I.C.L.-P. and A.M.C.-S.; methodology: M.A.-C., A.M.C.-S., L.O.-C., and M.M.C.-P.; supervision: I.C.L.-P.; writing-original draft preparation: I.C.L.-P. and L.O.-C.; writing-review and editing: I.C.L.-P., A.M.C.-S. and M.A.-C. All authors have read and agreed to the published version of the manuscript.

Funding: This research received no external funding.

Institutional Review Board Statement: Not applicable.

Informed Consent Statement: Not applicable.

Data Availability Statement: All available data can be obtained by contacting the corresponding author.

Conflicts of Interest: The authors declare no conflict of interest.

\section{References}

1. Aapro, M.; Piccart, M. Breast cancer. Crit. Rev. Oncol. Hematol. 1998, 27, 135-137. [CrossRef]

2. Bray, F.; Ren, J.; Masuyer, E.; Ferlay, J. Global estimates of cancer prevalence for 27 sites in the adult population in 2008. Int. J. Cancer 2013, 132, 1133-1145. [CrossRef]

3. Naghavi, M.; Abajobir, A.; Abbafati, C.; Abbas, K.; Abd-Allah, F.; Abera, S.F.; Aboyans, V.; Adetokunboh, O.; Afshin, A.; Agrawal, A.; et al. Global, regional, and national age-sex specific mortality for 264 causes of death, 1980-2016: A systematic analysis for the Global Burden of Disease Study 2016. Lancet 2017, 390, 1151-1210. 
4. Fitzmaurice, C.; Akinyemiju, T.; Al Lami, F.; Alam, T.; Alizadeh-Navaei, R.; Allen, C.; Alsharif, U.; Alvis-Guzman, N.; Amini, E.; Anderson, B.O.; et al. Global, Regional, and National Cancer Incidence, Mortality, Years of Life Lost, Years Lived with Disability, and Disability-Adjusted Life-Years for 29 Cancer Groups, 1990 to 2016. JAMA Oncol. 2018, 4, 1553.

5. Rojas, K.; Stuckey, A. Breast Cancer Epidemiology and Risk Factors. Clin. Obstet. Gynecol. 2016, 59, 651-672. [CrossRef]

6. Tabar, L.; Dean, P.B.; Chen, T.H.; Yen, A.M.-F.; Chen, S.L.S.; Fann, J.C.Y.; Chiu, S.Y.-H.; Ku, M.M.-S.; Wu, W.Y.; Hsu, C.-Y.; et al. The incidence of fatal breast cancer measures the increased effectiveness of therapy in women participating in mammography screening. Cancer 2019, 125, 515-523. [CrossRef]

7. Howlader, N.; Noone, A.M.; Krapcho, M.; Miller, D.; Bishop, K.; Altekruse, S.F.; Kosary, C.L.; Yu, M.; Ruhl, J.; Tatalovich, Z.; et al. SEER Cancer Statistics Review, 1975-2013; National Cancer Institute: Bethesda, MD, USA, 2016; Based on November 2015 SEER Data Submission, Posted to the SEER Web Site, April 2016. Available online: https:/ / seer.cancer.gov/archive/csr/1975_2013/ (accessed on 1 December 2020).

8. Warpenburg, M.J. Deep Friction Massage in Treatment of Radiation-induced Fibrosis: Rehabilitative Care for Breast Cancer Survivors. Integr. Med. 2014, 13, 32-36.

9. Runowicz, C.D.; Leach, C.R.; Henry, N.L.; Henry, K.S.; Mackey, H.T.; Cowens-Alvarado, R.L.; Cannady, R.S.; Pratt-Chapman, M.L.; Edge, S.B.; Jacobs, L.A.; et al. American Cancer Society / American Society of Clinical Oncology Breast Cancer Survivorship Care Guideline. CA Cancer J. Clin. 2016, 66, 43-73. [CrossRef]

10. Lazovich, D.; Solomon, C.C.; Thomas, D.B.; Moe, R.E.; White, E. Breast conservation therapy in the United States following the 1990 National Institutes of Health Consensus Development Conference on the treatment of patients with early stage invasive breast carcinoma. Cancer 1999, 86, 628-637. [CrossRef]

11. Douay, N.; Akerman, G.; Clément, D.; Malartic, C.; Morel, O.; Barranger, E. Seroma after axillary lymph node dissection in breast cancer. Gynecol. Obstet. Fertil. 2008, 36, 130-135. [CrossRef]

12. Francis, W.; Abghari, P.; Du, W.; Rymal, C.; Suna, M.; Kosir, M. Improving surgical outcomes: Standardizing the reporting of incidence and severity of acute lymphedema after sentinel lymph node biopsy and axillary lymph node dissection. Am. J. Surg. 2006, 192, 636-639. [CrossRef] [PubMed]

13. Kitamura, Y.; Ohno, Y.; Kasahara, S.; Murata, K.; Sugiyama, H.; Oshima, A.; Tsukuma, H.; Ajiki, W.; Hasegawa, T. Statistical estimation of the number of breast cancer patients with disabilities resulting from surgery. Breast Cancer 2005, 12, 130-134. [CrossRef] [PubMed]

14. Madsen, A.; Haugaard, K.; Soerensen, J.; Bokmand, S.; Friis, E.; Holtveg, H.; Garne, J.; Horby, J.; Christiansen, P. Arm morbidity following sentinel lymph node biopsy or axillary lymph node dissection: A study from the danish breast cancer cooperative. Breast 2007, 10, 291-401.

15. Nesvold, I.; Dahl, A.; Løkkevik, E.; Marit Mengshoel, A.; Fosså, S. Arm and shoulder morbidity in breast cancer patients after breast-conserving therapy versus mastectomy. Acta Oncol. 2008, 47, 835-842. [CrossRef] [PubMed]

16. Moore, G.J.; Mendenhall, N.P.; Kamath, S.S.; Lind, S.S.; Haigh, L.S.; Copeland, E.M. Persistent symptomatology after breast conservation therapy: Prevalence and impact on quality of life. Int. J. Radiat. Oncol. Biol. Phys. 1998, 42, 2058. [CrossRef]

17. Bentzen, S.M.; Thames, H.D.; Overgaard, M. Latent-time estimation for late cutaneous and subcutaneous radiation reactions in a single-follow-up clinical study. Radiother. Oncol. 1989, 15, 267-274. [CrossRef]

18. Dupilka, A.; Gramling, K. Radiation Side Effects and Syndromes. Available online: http:/ /www.physio-pedia.com/Radiation_ Side_Effects_and_Syndromes (accessed on 21 April 2014).

19. Stubblefield, M.D. Radiation fibrosis syndrome: Neuromuscular and musculoskeletal complications in cancer survivors. PMER 2011, 3, 1041-1054.

20. McDuff, S.G.R.; Mina, A.I.; Brunelle, C.L.; Salama, L.; Warren, L.E.; Abouegylah, M.; Swaroop, M.; Skolny, M.N.; Asdourian, M.; Gillespie, T.; et al. Timing of Lymphedema After Treatment for Breast Cancer: When Are Patients Most At Risk? Int. J. Radiat. Oncol. Biol. Phys. 2019, 103, 62-70. [CrossRef]

21. Warren, L.E.G.; Miller, C.L.; Horick, N.; Skolny, M.N.; Jammallo, L.S.; Sadek, B.T.; Shenouda, M.N.; O’Toole, J.A.; MacDonald, S.M.; Specht, M.C. The impact of radiation therapy on the risk of lymphedema after treatment for breast cancer: A prospective cohort study. Int. J. Radiat. Oncol. Biol. Phys. 2014, 88, 565-571. [CrossRef]

22. Norman, S.A.; Localio, A.R.; Potashnik, S.L.; Torpey, H.A.S.; Kallan, M.J.; Weber, A.L.; Miller, L.T.; DeMichele, A.; Solin, L.J. Lymphedema in breast cancer survivors: Incidence, degree, time course, treatment, and symptoms. J. Clin. Oncol. 2009, 27, 390-397. [CrossRef]

23. DiSipio, T.; Rye, S.; Newman, B.; Hayes, S. Incidence of unilateral arm lymphoedema after breast cancer: A systematic review and meta-analysis. Lancet Oncol. 2013, 14, 500-515. [CrossRef]

24. Togawa, K.; Ma, H.; Sullivan-Halley, J.; Neuhouser, M.L.; Imayama, I.; Baumgartner, K.B.; Smith, A.W.; Alfano, C.M.; McTiernan, A.; Ballard-Barbash, R.; et al. Risk factors for self-reported arm lymphedema among female breast cancer survivors: A prospective cohort study. Breast Cancer Res. 2014, 16, 414. [CrossRef]

25. Rupp, J.; Hadamitzky, C.; Henkenberens, C.; Christiansen, H.; Steinmann, D.; Bruns, F. Frequency and risk factors for arm lymphedema after multimodal breast-conserving treatment of nodal positive breast Cancer-A long-term observation. Radiat. Oncol. 2019, 14, 39. [CrossRef]

26. Ridner, S.H. Quality of life and symptom cluster associated with breast cancer treatment-related lymphedema. Support. Care Cancer 2005, 13, 904-911. [CrossRef] [PubMed] 
27. Edmond, S.N.; Shelby, R.A.; Keefe, F.J.; Fisher, H.M.; Schmidt, J.; Soo, M.S.; Skinner, C.S.; Ahrendt, G.M.; Manculich, J.; Sumkin, J.H.; et al. Persistent Breast Pain Among Women with Histories of Breast-Conserving Surgery for Breast Cancer Compared with Women without Histories of Breast Surgery or Cancer. Clin. J. Pain 2017, 33, 51-56. [CrossRef]

28. Bruce, J.; Thornton, A.; Powell, R.; Johnston, M.; Wells, M.; Heys, S.; Thompson, A.M.; Smith, W.C.; Chambers, W.A.; Scott, N.W.; et al. Psychological, surgical, and sociodemographic predictors of pain outcomes after breast cancer surgery: A population-based cohort study. Pain 2014, 155, 232-243. [CrossRef] [PubMed]

29. Blumen, H.; Fitch, K.; Polkus, V. Comparison of Treatment Costs for Breast Cancer, by Tumor Stage and Type of Service. Am. Health Drug Benefits 2016, 9, 23-32. [PubMed]

30. De Groef, A.; Van Kampen, M.; Dieltjens, E.; Christiaens, M.; Neven, P.; Geraerts, I.; Devoogdt, N. Effectiveness of Postoperative Physical Therapy for Upper-Limb Impairments After Breast Cancer Treatment: A Systematic Review. Arch. Phys. Med. Rehabil. 2015, 96, 1140-1153. [CrossRef] [PubMed]

31. Borstad, J.; Ludewig, P. The Effect of Long Versus Short Pectoralis Minor Resting Length on Scapular Kinematics in Healthy Individuals. J. Orthop. Sports Phys. Ther. 2005, 35, 227-238. [CrossRef]

32. McNeely, M.; Campbell, K.; Ospina, M.; Rowe, B.; Dabbs, K.; Klassen, T.; Mackey, J.; Courneya, K. Exercise interventions for upper-limb dysfunction due to breast cancer treatment. Cochrane Database Syst. Rev. 2010, 6, CD005211. [CrossRef]

33. Pilat, A. Myofascial induction approaches. In Fascia: The Tensional Network of the Human Body. The Science and Clinical Applications in Manual and Movement Therapy; Churchill Livingstone: London, UK, 2011; p. 455.

34. Rodríguez-Huguet, M.; Gil-Salú, J.L.; Rodríguez-Huguet, P.; Cabrera-Afonso, J.R.; Lomas-Vega, R. Effects of Myofascial Release on Pressure Pain Thresholds in Patients with Neck Pain: A Single-Blind Randomized Controlled Trial. Am. J. Phys. Med. Rehabil. 2018, 97, 16-22. [CrossRef]

35. Chamorro Comesaña, A.; del Suárez Vicente, M.P.; Docampo Ferreira, T.; del Pérez-La Fuente Varela, M.M.; Porto Quintáns, M.M.; Pilat, A. Effect of myofascial induction therapy on post-c-section scars, more than one and a half years old. Pilot study. J. Bodyw. Mov. Ther. 2017, 21, 197-204. [CrossRef] [PubMed]

36. Ozsoy, G.; Ilcin, N.; Ozsoy, I.; Gurpinar, B.; Buyukturan, O.; Buyukturan, B.; Kararti, C.; Sas, S. The Effects Of Myofascial Release Technique Combined with Core Stabilization Exercise in Elderly with Non-Specific Low Back Pain: A Randomized Controlled, Single-Blind Study. Clin. Interv. Aging 2019, 14, 1729-1740. [CrossRef] [PubMed]

37. Ceca, D.; Elvira, L.; Guzmán, J.F.; Pablos, A. Benefits of a self-myofascial release program on health-related quality of life in people with fibromyalgia: A randomized controlled trial. J. Sports Med. Phys. Fit. 2017, 57, 993-1002.

38. Urrútia, G.; Bonfill, X. Declaración Prisma: Una propuesta para mejorar la publicación de revisiones sistemáticas y metaanálisis. Med. Clin. 2010, 135, 507-511. [CrossRef]

39. Da Costa Santos, C.M.; de Mattos Pimenta, C.A.; Nobre, M.R. The PICO strategy for the research question construction and evidence search. Rev. Lat. Am. Enferm. 2007, 15, 508-511. [CrossRef]

40. Fernández-Lao, C.; Cantarero-Villanueva, I.; Díaz-Rodríguez, L.; Fernández-de-las-Peñas, C.; Sánchez-Salado, C.; Arroyo-Morales, M. The Influence of Patient Attitude Toward Massage on Pressure Pain Sensitivity and Immune System after Application of Myofascial Release in Breast Cancer Survivors: A Randomized, Controlled Crossover Study. J. Manip. Physiol. Ther. 2012, 35, 94-100. [CrossRef]

41. Fernández-Lao, C.; Cantarero-Villanueva, I.; Díaz-Rodríguez, L.; Cuesta-Vargas, A.; Fernández-Delas-Peñas, C.; Arroyo-Morales, M. Attitudes towards massage modify effects of manual therapy in breast cancer survivors: A randomised clinical trial with crossover design. Eur. J. Cancer Care 2011, 21, 233-241. [CrossRef] [PubMed]

42. De Groef, A.; Van Kampen, M.; Vervloesem, N.; De Geyter, S.; Christiaens, M.; Neven, P.; Vos, L.; de Vrieze, T.; Geraerts, I.; Devoogdt, N. Myofascial techniques have no additional beneficial effects to a standard physical therapy programme for upper limb pain after breast cancer surgery: A randomized controlled trial. Clin. Rehabil. 2017, 31, 1625-1635. [CrossRef]

43. Castro-Martín, E.; Ortiz-Comino, L.; Gallart-Aragón, T.; Esteban-Moreno, B.; Arroyo-Morales, M.; Galiano-Castillo, N. Myofascial Induction Effects on Neck-Shoulder Pain in Breast Cancer Survivors: Randomized, Single-Blind, Placebo-Controlled Crossover Design. Arch. Phys. Med. Rehabil. 2017, 98, 832-840. [CrossRef]

44. Serra-Añó, P.; Inglés, M.; Bou-Catalá, C.; Iraola-Lliso, A.; Espí-López, G. Effectiveness of myofascial release after breast cancer surgery in women undergoing conservative surgery and radiotherapy: A randomized controlled trial. Support. Care Cancer 2018, 27, 2633-2641. [CrossRef]

45. De Groef, A.; Van Kampen, M.; Verlvoesem, N.; Dieltjens, E.; Vos, L.; De Vrieze, T.; Christiaens, M.-R.; Neven, P.; Geraerts, I.; Devoogdt, N. Effect of myofascial techniques for treatment of upper limb dysfunctions in breast cancer survivors: Randomized controlled trial. Support. Care Cancer 2017, 25, 2119-2127. [CrossRef]

46. De Groef, A.; Van Kampen, M.; Vervloesem, N.; Dieltjens, E.; Christiaens, M.; Neven, P.; Vos, L.; de Vrieze, T.; Geraerts, I.; Devoogdt, N. Effect of myofascial techniques for treatment of persistent arm pain after breast cancer treatment: Randomized controlled trial. Clin. Rehabil. 2017, 32, 451-461. [CrossRef]

47. Massingill, J.; Jorgensen, C.; Dolata, J.; Sehgal, A. Myofascial Massage for Chronic Pain and Decreased Upper Extremity Mobility After Breast Cancer Surgery. Int. J. Ther. Massag. Bodyw. Res. Educ. Pract. 2018, 11, 4-9.

48. Webb, T.R.; Rajendran, D. Myofascial techniques: What are their effects on joint range of motion and pain? A systematic review and meta-analysis of randomised controlled trials. J. Bodyw. Mov. Ther. 2016, 20, 682-699. [CrossRef] [PubMed] 
49. Burk, C.; Perry, J.; Lis, S.; Dischiavi, S.; Bleakley, C. Can Myofascial Interventions have a remote effect on ROM? A systematic Review and Meta-analysis. J. Sport Rehabil. 2020, 29, 650-656. [PubMed]

50. Pinheiro Da Silva, F.; Moreira, G.M.; Zomkowski, K.; Amaral de Noronha, M.; Flores Sperandio, F. Manual therapy as treatment for chronic musculoskeletal pain in female breast cancer survivors: A systematic review and meta-analysis. J. Manip. Physiol. Ther. 2019, 42, 504-513. [CrossRef] [PubMed]

51. Deng, G. Integrative Medicine Therapies for Pain Management in Cancer Patients. Cancer J. 2019, 25, 343-348. [CrossRef]

52. Pilat, A. Myofascial Therapies: Myofascial Induction; McGraw-Hill Interamericana: Madrid, Spain, 2003.

53. Bjerkeset, E.; Rhrl, K.; Schou-Bredal, I. Symptom cluster of pain, fatigue, and psychological distress in breast cancer survivors: Prevalence and characteristics. Breast Cancer Res. Treat. 2020, 180, 63-71. [CrossRef] [PubMed] 